\title{
WEALTH AND ASSET PRICE EFFECTS ON \\ ECONOMIC ACTIVITY
}

by Filippo Altissimo,

Evaggelia Georgiou,

Teresa Sastre,

Maria Teresa Valderrama,

Gabriel Sterne, Marc Stocker,

Mark Weth, Karl Whelan

and Alpo Willman 
EUROPEAN CENTRAL BANK

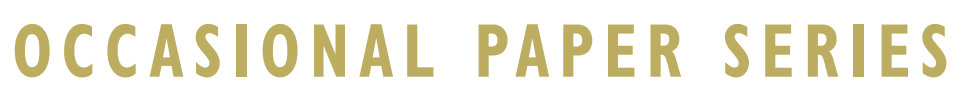

NO. 29 I JUNE 2005

\section{WEALTH AND ASSET PRICE EFFECTS ON ECONOMIC ACTIVITY '}

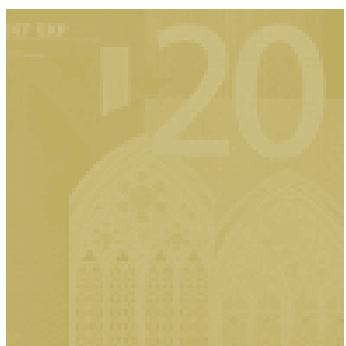

by Filippo Altissimo, Evaggelia Georgiou, Teresa Sastre, Maria Teresa Valderrama,

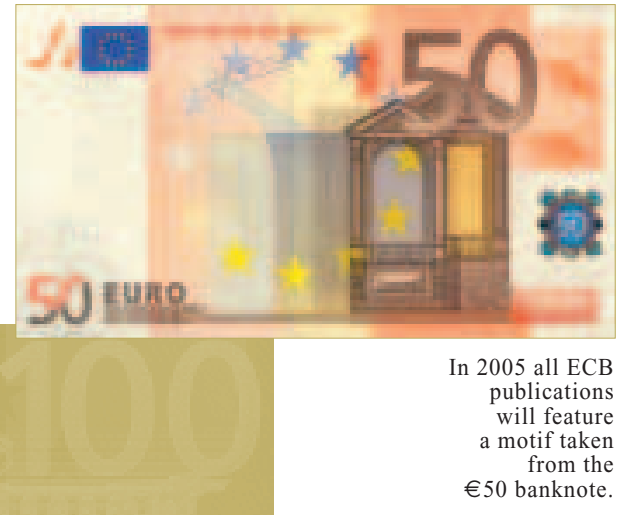
Gabriel Sterne, Marc Stocker, Mark Weth, Karl Whelan and Alpo Willman

This paper can be downloaded from the ECB's website (http://www.ecb.int). 
(C) European Central Bank, 2005

Address

Kaiserstrasse 29

60311 Frankfurt am Main

Germany

Postal address

Postfach 160319

60066 Frankfurt am Main

Germany

Telephone

+496913440

Website

http://www.ecb.int

Fax

+496913446000

Telex

411144 ecb d

All rights reserved. Reproduction for educational and non-commercial purposes is permitted provided that the source is acknowledged.

The views expressed in this paper do not necessarily reflect those of the European Central Bank.

ISSN 1607-1484 (print)

ISSN 1725-6534 (online) 


\section{CONTENTS}

\section{INTRODUCTION}

\section{WEALTH CHANNEL}

2.1 A theoretical review

2.1.1 Implications of the lifetime budget constraint

2.1.2 Implications of risk aversion

2.1.3 Implications of income uncertainty

2.1.4 Do marginal propensities to consume out of different wealth components differ?

2.1.4.1 Implications of market imperfections, taxation and diversified bequest motives

2.1.4.2 Implications of the (un)predictability of asset prices

2.1.4.3 Marginal propensities to consume out of non-equity financial wealth, equity wealth and housing wealth I

2.2 Some conclusions

3 HOUSEHOLD WEALTH: A STATISTICAL REVIEW

3.1 Decomposition of household wealth into financial and housing wealth

3.2 Decomposition of household financial wealth to components

3.3 Equity wealth effect, income distribution and demographics

\section{ASSET PRICE EFFECTS VIA THE WEALTH} CHANNEL: EMPIRICAL EVIDENCE

4.1 Micro data evidence

4.2 The MPC out of wealth in some calibrated theory-based models

\section{ASSET PRICES AND INVESTMENT}

5.1 Equity prices and corporate investment

5.2 Tobin's Q or cost-of-capital channel

\section{CONCLUSIONS}

\section{APPENDIXES}

1 Comparability of equity wealth data across countries

2 The US evidence on wealth effects on consumption

3 Balance sheet channel 45 
I

\section{INTRODUCTION}

Do asset prices affect real activity? This question has taken on a new importance in recent years, as asset values first surged at the end of $1990 \mathrm{~s}$ and, thereafter, dramatically retreated. The macroeconomic importance of this phenomenon is illustrated by Figure 1, which presents stock market capitalisation as a percentage of GDP in some major industrialised countries. From the 1970 s to the late 1990s this ratio rose six to eightfold in all countries (except in Japan). However, subsequently it fell markedly, and in 2002 it had declined to around half of its late 1990s peak. In 2003 the stock market capitalisation ratio began to recover moderately. It is therefore natural to ask how much of this variation has been transmitted into economic activity?

There are four channels through which stock prices can be considered to affect activity: (1) the wealth effect on consumption, (2) the Tobin's Q effect on investment, (3) the balance sheet effect on private spending (via the credit channel) and (4) the confidence effect on private spending. The approach that we follow

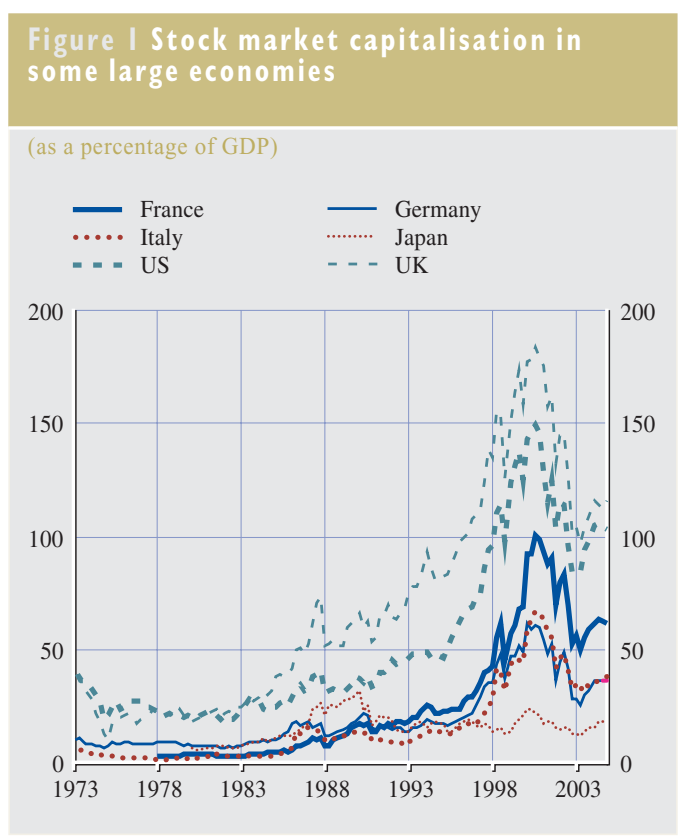

in this report is that of partial equilibrium rather than general equilibrium, because the focus is on the transmission of asset price effects on activity via these channels. Our aim is to review the evidence contained in the recent and fast growing literature. The main text concentrates on the first two channels, as distinguishing the balance sheet and confidence effects from those transmitted via the wealth and Tobin's Q channel is, at least in the macro data, very difficult. However, balance sheet and confidence channels are discussed in Appendix 3 of this report. Section 2 presents the theoretical background of the wealth channel. A statistical review of the wealth composition across countries is given in Section 3. The empirical evidence on the effects of wealth and its main components on consumption is reviewed in Section 4. The effect of asset prices on investment via Tobin's $\mathrm{Q}$ channel is reviewed in Section 5 and Section 6 concludes.

\section{WEALTH CHANNEL}

The wealth channel has sound theoretical foundations. Consumers intertemporal utility maximisation under a lifetime resource constraint, states that current consumption is proportional to total wealth,

$$
\begin{aligned}
C= & m p c_{W}[A+H(Y)] \\
& \approx m p c_{W} A+m p c_{Y} Y
\end{aligned}
$$

where $C$ is consumption, $A$ is real non-human wealth and $H$ is real human wealth, i.e. the present value of expected labour income (net of taxes) $Y$. The proportionality coefficients $m p c$ measure the marginal propensity to consume (MPC) out of wealth and income, respectively. As, by definition, labour income and human wealth are co-integrated, a long-run relation for consumption can also be presented as the weighted average of non-human wealth and labour income, both of which are observable variables. From the point of view of the macroeconomic importance of the wealth channel, it is illuminating to transform (2.1) into an elasticity form as follows, 


$$
\begin{aligned}
\frac{\Delta C}{C} & =\underbrace{\left.m p c_{W} \frac{A}{C}\right]}_{e_{W}} \frac{\Delta A}{A}+\underbrace{\left[m p c_{Y} \frac{Y}{C}\right]}_{1-e_{W}} \frac{\Delta Y}{Y} \\
& =\sum \underbrace{m p c_{w} \frac{A}{C}}_{e_{W, j}} \frac{\Delta A_{j}}{A_{j}}+\left[m p c_{Y} \frac{Y}{C}\right] \frac{\Delta Y}{Y}
\end{aligned}
$$

be expected in the light of underlying economic theory. Therefore, the quality of the data used in the alternative studies is assessed. Finally a summarised view on the size of the MPC out of wealth is proposed based on the aggregate panel data evidence.

\section{I A THEORETIC REVIEW}

The relation (2.2) shows that the size of wealth elasticity of consumption $e_{W}$ depends, in addition to $m p c_{W}$, on the size of the wealth consumption ratio or, if differentiated across wealth components, on the wealth consumption ratio of each wealth component $j$. We can also see that the elasticity $e_{W}$ (or $e_{W j}$ ), is constant only if the wealth (or the wealth component $j$ ) to consumption ratio is constant. Given the wide variations in the wealth to income ratio indicated by Figure 1 and theoretical priors suggesting a constant or stationary MPC, this implies that the logarithmic specification in estimation may be functionally misspecified, especially when wealth is disaggregated into components. Hence, the direct estimation of MPCs should be preferred to the estimation of elasticities. Unfortunately this contrasts with general practice, which has favoured logarithmic transformation in estimation.

In the following we first concentrate on the MPC out of wealth. We start by reviewing what theory suggests concerning the determinants and appropriate size of the MPC out of wealth. In addition, we consider whether the size of the MPC out of wealth should be the same across countries and across wealth components and, if not, then why not? Section 3 compares the composition of wealth across countries. In Section 4 we shift to the evidence given by studies based on the use of both micro and macro data. These studies can be classified into three approaches: theory-based calibration, estimated consumption functions with parameter constraints imposed by economic theory and direct estimation without theoryimposed constraints. Our conclusion is that there is considerably more variation in the estimates presented in these studies than would
In the following we take a closer look at the wealth effect on consumer expenditure. We first study the implications of the household intertemporal budget constraint without any reference to risk aversion. Thereafter we study the impact of risk-aversion on the MPC out of wealth in the framework of the finitely living overlapping generation model by Blanchard (1985). Then the effects of income uncertainty are discussed and, more heuristically, the likely effects of market imperfections and distortionary taxation are discussed. Finally, we consider the implications of dividing asset price movements into permanent and transitory components for the asset price effects on consumption.

\section{I.I IMPLICATIONS OF THE LIFETIME BUDGET CONSTRAINT}

The logic of budget constraints dictates that, when an individual's wealth rises, the individual must either spend that wealth while living, or leave the money to other individuals, charities or the government after death. Nevertheless, the central issue in analysing wealth effects is timing. If the lag between a favourable shock to the household balance sheet and an increase in consumption spending takes many years to develop, then market fluctuations may have a limited impact on aggregate spending. However, if the link from net worth to consumption is powerful and immediate, then sharp changes in asset values may translate into sharp changes in consumer spending. The following more formal presentation tries to deepen this insight.
2 WEALTH CHANNEL 
Conventional budget constraints faced by households can be written as follows:

$$
\text { (2.3) } A_{t+1}=R_{a, t+1}\left[A_{t}+Y_{t}-C_{t}\right] \text {, }
$$

where $A_{t}$ is the aggregate level of real and financial assets at the end of period $t, Y_{t}$ is nonproperty income (i.e. labour income), $C_{\mathrm{t}}$ is consumption and $R_{a, t+1}\left(=1+\mathrm{r}_{a, t+1}\right)$ is a timevarying return on total assets. If $A_{t}$ contains both riskless and risky assets, then $R_{a, t}$ can be interpreted as a weighted average of the returns of these assets. By solving forward and imposing the transversality condition that at the end of a finite horizon the limit of discounted future wealth is zero, we obtain:

$$
\begin{aligned}
& E_{t} \sum_{i=1}^{T}\left(\prod_{j=0}^{i} R_{a, t}^{-1} R_{a, t+j}\right)^{-1} C_{t+i} \\
& =A_{t}+\underbrace{E_{t} \sum_{i=1}^{T}\left(\prod_{j=0}^{i} R_{a, t}^{-1} R_{a, t+j}\right)^{-1} Y_{t+i}}_{H_{t}}
\end{aligned}
$$

Equation (2.4) tells us that today's total wealth, which is the sum of real and financial assets and the discounted sum of expected future labour income $\left(W_{t}=A_{t}+H_{t}\right)$, equals the discounted value of the planned future consumption. Furthermore, (2.4) implies that as a response to a permanent unanticipated wealth shock the discounted sum of future consumption must rise by an equal amount, i.e.

$$
\begin{gathered}
\Delta A_{t}=E_{t} \sum_{i=1}^{T}\left(\prod_{j=0}^{i} R_{a, t}^{-1} R_{a, t+j}\right)^{-1} \Delta C_{t+i} \\
\approx\left(\frac{1-\bar{R}_{a}^{-T}}{1-\bar{R}_{a}^{-1}}\right) \Delta \bar{C} \\
\Delta \bar{C}=\underbrace{\frac{\bar{r}_{a}}{1+\bar{r}_{a}}\left[\frac{\left(1+\bar{r}_{a}\right)^{T}}{\left(1+\bar{r}_{a}\right)^{T}-1}\right] \Delta A_{t}}_{m p c_{W}}
\end{gathered}
$$

where

$$
\mathrm{mpc}_{\mathrm{w}}=\left\{\begin{array}{cc}
\left(\frac{\bar{r}_{a}}{1+\bar{r}_{a}}\right) \text { when } T \rightarrow \infty \\
1 & \text { when } T \rightarrow 1
\end{array}\right.
$$

where $\Delta$ indicates the difference between the post-shock and pre-shock values, $\Delta \bar{C}$ refers to the average level shift in consumption over the horizon from $t$ to $T$ and $1+r_{a}=\bar{R}_{a}$ is the average return on non-human wealth over the horizon from $t$ to $T$. Equation (2.5) defines the long-run MPC out of wealth $m p c_{W}$ conditional on the positive wealth shock being permanent. In addition to being dependent on the expected average return on non-human wealth it is affected by the horizon of the representative consumer.

To anchor the empirical analysis of how wealth affects consumer spending, Table 2.1 follows Poterba (2000), presenting some benchmark estimates of the amount by which a household might increase its consumption if it received a favourable wealth shock. Table 2.1 reports values for a feasible annual permanent increase in consumption (MPC out of wealth), expressed in cents per one euro (dollar) increase in wealth, for the ranges of alternative planning horizons and the average expected returns on non-human wealth.

The length of planning horizon: For example, a household with a 30-year planning horizon that faces a $3 \%$ real return of wealth can raise consumption outlays by five cents for each one euro increase in wealth. In addition, Table 2.1 shows that the length of planning horizon is important; the shorter the horizon the higher

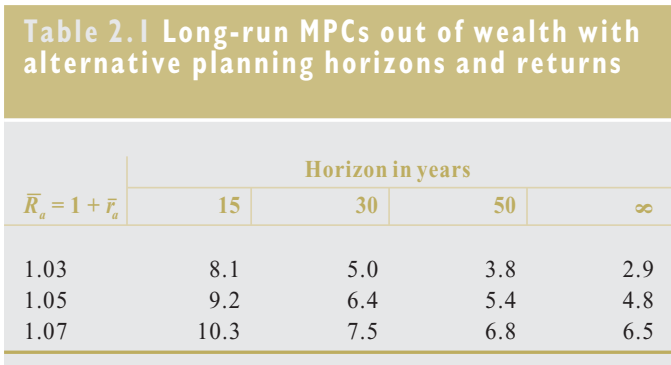


the MPC out of wealth. This relation is nonlinear so that MPC out of wealth values corresponding to the 30-year horizon are closer to MPC out of wealth values implied by an infinite horizon than those implied by a 15 -year horizon.

The following two factors, among others, may affect the length of the planning horizon and hence the aggregate level of the MPC out of wealth.

- It is natural to associate the length of planning horizon with the expected remaining lifetime. At a macro level an implication might be that the more concentrated wealth is in older generations the shorter the planning horizon of the "average" wealth owner and the higher the MPC out of wealth

- On the other hand, a strong bequest motive affects the MPC out of wealth largely in the same way as the lengthening of the planning horizon (see, for instance, the discussion by Campbell and Viceira, 1999).

The rate of return on real and financial assets: Another determinant of the MPC out of wealth is the expected rate of return on assets. The higher it is, the higher is the MPC out of wealth. However, the required rates of return may differ across wealth components, reflecting the risks associated with them. Therefore, as the relevant discounting rate of the consumption stream is the weighted average of the rates of return of individual wealth components, the allocation of wealth across risky and less risky assets matters. More specifically, an increase in the portfolio share of risky assets should increase the MPC out of wealth. In addition, if risk premiums vary over time, a standard assumption in the current financial literature, then the MPC out of wealth should also be time-varying. This empirically testable hypothesis is discussed in Section 4 and Appendix 2 of this report. However, time variation of the MPC out of wealth may be reduced if the rate of return used in discounting the planned consumption stream is not the current period rate of return, but the expected average over the planning horizon.

\section{I.2 IMPLICATIONS OF RISK AVERSION}

The above analysis, based on the lifetime budget constraint, was not able to account for the possible effects of risk aversion on consumption. Therefore, let us assume the following instantaneous constant relative riskaversion (CRRA) utility function $\frac{\sigma}{\sigma-1} C_{t}\left(\frac{\sigma-1}{\sigma}\right)$, where $\sigma \geq 0$ is the intertemporal elasticity of substitution (the inverse of relative risk aversion). Now, in Blanchard's (1985) finitely living overlapping generations model with the constant probability of death $\pi$, intertemporal utility maximisation yields the following MPC out of total wealth:

$$
m p c_{W}=\frac{r_{W}+\pi}{\left(1+r_{W}\right)(1-\pi)} \approx r_{W}+\pi
$$

with the risk-adjusted return $r_{W}$ defined by

$$
r_{W}=(1+\rho)^{\sigma}\left(1+r_{a}\right)^{1-\sigma}-1 \approx \sigma \cdot \rho+(1-\sigma) \cdot r_{a}
$$

and where $\rho$ is the subjective discount rate. According to (2.6), $m p c_{W}$ is positively related to the "risk-adjusted" return $r_{W}$ as well as to the probability of death (i.e. the inverse of the expected lifetime $\left.T^{e}=1 / \pi\right)$. Equation (2.7) defines $r_{W}$ as a weighted average of the subjective discount rate $\rho$ and the rate of return on wealth $r$. When varying the "risk-adjusted" return $r_{W}$ and the expected lifetime $T^{e}=1 / \pi$ in the same range as we varied $r_{a}$ and $T$ in Table 2.1, relation (2.6) gives somewhat higher figures than those in Table 2.1. For instance, with $T^{e}=30$ the MPCs corresponding to the $r_{W}$ values of $3 \%, 5 \%$ and $7 \%$ would be $6.3,8.6$ and 10.3 cents per one euro permanent increase in wealth, respectively. These figures are somewhat higher than corresponding figures in Table 2.1 (i.e. 5, 6.4 and 7.5 cents). On the other hand, as shown in Figure 2.1, if $0<\sigma \leq 1$, which implies high risk-aversion, $r_{W}$ and $m p c_{W}$ are only partially dependent on the real rate of return $r_{a}$. However, with low risk-aversion, $\sigma>1$, the long-run real risk-free interest rate 


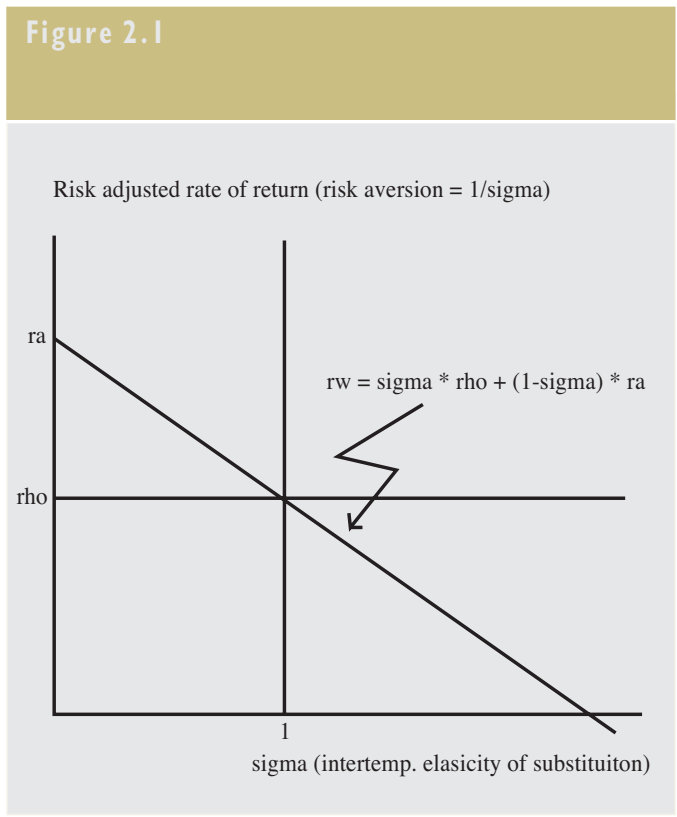

(or the subjective discount rate) is no longer the lower bound for $m p c_{w}$, as the sign of the dependence of $m p c_{W}$ on $r_{a}$ changes from positive to negative. Combining very high intertemporal elasticity of substitution (i.e. very low risk aversion) with the plausible assumption that the real return of wealth $r_{a}>\rho$, even negative values for $m p c_{W}$ cannot be ruled out.

Accordingly, the analysis in the previous section must be extended to consider households' attitudes to risk. When the real rate of return on wealth $r$ is higher than the subjective discount rate, equations (2.6) and (2.7) imply that $\frac{\partial m p c_{W}}{\partial \sigma}<0$, i.e. a decrease in risk aversion decreases the MPC out of wealth.

What then is a plausible the size of $m p c_{W}$ ? This largely depends on whether $\sigma$ is below or above unity. Estimates of $\sigma$ both below and above unity can be found in the literature, although most are below unity. For example, much of the real business cycle (RBC) literature assumes an elasticity of intertemporal substitution between a half and one. Recently, Smets and Wouters (2002) estimated the elasticity of substitution at 0.6 with euro area data. Applying this estimate and the assumption that the subjective discount rate is around the average long-term government bond rate (around 3-4\%), relation (2.6) produces, with the same values for $r_{a}$ and $T^{e}$, a range of $m p c_{W}$ values similar to that presented in Table 2.1.

\section{I.3 IMPLICATIONS OF INCOME UNCERTAINTY}

What about uncertainty concerning labour income? Does it affect the MPC out of wealth? As closed form decision rules for optimal consumption in the presence of uncertain labour income cannot in general be derived, Zeldes (1989) used numerical methods to closely approximate the optimal consumption function and the corresponding value function for some multi-period problems with uncertain labour income. One of the most striking features for his numerical solutions for the consumption rule under uncertainty was the introduction of concavity to consumption rules that were linear in the absence of uncertainty. Income uncertainty makes the MPC out of wealth state dependent, i.e. the MPC out of wealth of a consumer with low wealth was markedly higher than that of a consumer with high wealth. Later Carroll and Kimball (1996) have confirmed that result analytically. They showed that, except under very special conditions, adding income uncertainty to the standard optimisation problem induces a concave consumption function in which the MPC out of wealth declines along with the increasing level of wealth.

\section{I.4 DO MARGINAL PROPENSITIES TO CONSUME OUT OF DIFFERENT WEALTH COMPONENTS DIFFER?}

Total wealth is not homogenous, but consists of several components with different risk, collateral and liquidity properties. In addition, the services associated with each wealth component vary widely. Therefore, the MPC out of each wealth component may reflect these differences. In this section we briefly discuss this issue, with special attention paid to the MPC out of the three main components of

1 This effect is strengthened by the reasonable assumption that the risk premium $r_{a}-\rho$ also depends positively on the rate of risk aversion. 
household wealth, i.e. non-equity financial wealth, equity wealth and tangible (mainly housing) wealth.

\subsubsection{Implications of market imperfections, taxation and diversified bequest motives}

Typically the behaviour of utility maximising consumers is analysed assuming unbounded rationality, perfect capital markets and the absence of distorting taxes or rigidities. In these ideal circumstances, where the composition of wealth can be changed without friction or cost, the MPCs out of different wealth components should naturally be equal. However, this is no longer true when these assumptions are relaxed. In imperfect capital markets with distorting taxes and only boundedly rational consumers, the properties associated with different wealth components may well affect their respective MPC. For instance,

- The liquidity properties of alternative wealth components may be very different reflecting, for instance, the fact that the collateral markets for household borrowing are underdeveloped in most countries, or at least have been until recently. Now, if the only way for a house owner to increase consumption, as a response to a rise in housing value, is first to sell the house, it is quite evident that most house owners will not react to the increase in the market value of housing. Moreover, even in welldeveloped financial markets, the required capital adequacy ratios of banks may induce the banks to evaluate collateral values of assets below their market values. These arguments suggest that the MPC out of each wealth component depends positively on the liquidity of the asset in question and negatively on the ratio of the market value of the asset to its collateral value.

- From the point of view of the bequest motive, wealth components are not similar. For instance, property (including shares) coupled with entrepreneurship (e.g. the "family business") may be associated with a much stronger bequest motive and, hence, a lower MPC out of wealth, than other wealth components. In addition, fiscal distortions (e.g. estate taxes) may favour some assets for consumption and others for bequests.

- Similarly, Thaler (1994) argued that "mental accounting", which dictates that some assets are more appropriate for current consumption while others are better for long-term savings, may result in different MPCs out of wealth across wealth components. Many behavioural studies support this view. As saving requires willpower, it is easier for many consumers to save from lump-sum payments or from capital gains rather than from "regular income".

\subsubsection{Implications of the (un)predictability of asset prices}

Efficient financial markets are the underlying assumption in most of the macroeconomic modelling work. This hypothesis implies that asset prices follow a random walk so that all movements are unpredictable or, equivalently, all asset price movements are expected to be permanent. Under this interpretation, the expected rate of return (discount rate) is constant and changes in asset prices generate changes in consumption.

However, the underlying hypothesis of efficient financial markets with a constant discount rate (or constant expected rate of return) was challenged by Shiller (1981) and LeRoy and Porter (1981), who argued that stock returns were too volatile to be accounted for by variation in future dividend growth with constant discount rates. There is now a large and growing body of empirical literature in financial economics which finds that aggregate stock market returns are predictable over long horizons (see e.g. Shiller, 1984, Campbell and Shiller, 1988, Fama and French, 1988, Hodrick, 1992, Lamont, 1998, Lettau and Ludvigson, 2001, Campbell, 2001, Lewellen, 2001, and Campbell and Goto, 2002). This suggests that conditional expected returns, or 
discount rates, vary over time, possibly driven by cyclical variation in risk aversion (see e.g. Sundaresan, 1989, Constantinides, 1990, Campbell and Cochrane, 1999, and Cochrane, 2001, Chapter 20).

Campbell and Cochrane (1999) present a consumption-based model that explains, among a wide variety of dynamic asset-pricing phenomena, the long-run predictability of excess stock returns (mean reversion). The key element of their explanation is the timevarying habit, or subsistence, level of consumption added to the constant riskaversion utility function. However, in calibrating their model to actual data, they found that the process defining the habit level of consumption must be slow-moving and nonlinear to be able to generate mean reversion of asset prices. Although the question of whether these requirements are compatible with actual data is largely untested, Fuhrer (2000), for instance, found that one period lag of consumption, instead of its long lag distribution, was sufficient to capture the habit formation effect on consumption.

Anyway, independently from possible theoretical explanations, the division of asset price movements into the expected permanent and transitory components may affect the MPC out of equity wealth. To clarify this issue Lettau and Ludvigson (2001) used a more dataoriented approach. They examined the implications of the intertemporal budget constraint to the long-run cointegration relationship between consumption, income and wealth. Taking as their basis the work of Campbell and Mankiw (1989) and Campbell (1996), Lettau and Ludvigson (2001) showed that the $\log$ approximation of the budget constraint (2.4) can be presented in the following form (lowercase letters denote $\log$ variables):

(2.8) $c_{t}-\alpha \cdot a_{t}-(1-\alpha) y_{t}=$

$$
\begin{aligned}
& E_{t} \sum_{i=1}^{\infty} \rho_{w}^{i}\left\{\left[\alpha \cdot r_{a, t+i}+(1-\alpha) \cdot r_{h, t+i}\right]-\Delta c_{t+i}\right\}+(1-\alpha) z_{t} \\
\approx & E_{t} \sum_{i=1}^{\infty} \rho_{w}^{i}\left\{\left[\alpha \cdot \Delta a_{t+i}+(1-\alpha) \cdot r_{h, t+i}\right]-\Delta c_{t+i}\right\}+(1-\alpha) z_{t}
\end{aligned}
$$

where $r_{h, t+i}$ is real net return on human wealth and $r_{a, t+i} \approx \Delta a_{t+i}$, see Campbell, Lo and MacKinlay (1997). Parameter $\alpha$ is the average share of non-human wealth in total wealth (equalling approximately the GDP share of non-labour income) and $z_{t}$ is the residual of the cointegrating relationship between human wealth $h_{t}$ and labour income $y_{t}$. If all the righthand-side variables of (2.8) are presumed stationary, then $c, a$ and $y$ must be cointegrated, and the left-hand side of (2.8) gives the deviation in the common trend of $c_{t}, a_{t}$ and $y_{t}$.

It follows that the real effects of changes in the market valuation of wealth depend on how the adjustment burden of the cointegration residual implied by the left-hand side of (2.8) is fed back to consumption, labour income and the market value of non-financial wealth, reflecting fluctuations in expected returns on wealth. If the mean reversion tendency of asset prices is strong, which implies a strong transitory component in asset prices, dynamic effects on consumption may remain modest although the dynamic equation estimated for consumption would contain a large and significant coefficient for the lagged cointegration residual. This aspect is stressed by Lettau and Ludvigson (2002) and, especially, by Lettau, Ludvigson and Barczi (2001) in their comment on Davis and Palumbo (2001).

As a better summary statistic, which would account for the finding that much of the variation in wealth is transitory and uncorrelated with consumer spending, Lettau and Ludvigson (2002) propose the following corrected measure:

$$
m p c_{c o r r}=\left(\frac{\sqrt{\gamma}}{\sqrt{\gamma}+\sqrt{1-\gamma}}\right) m p c_{W} ; 0 \leq \gamma \leq 1
$$

where $\gamma$ is the is the share of the transitory component in the variance of wealth. 
However, as mean reversion in asset prices reflects fluctuations in expected returns on equity wealth, this issue is also related to the possible time-variance of the MPC out of wealth as is discussed by Palumbo et al. (2002) and in Appendix 2 of this report.

\subsubsection{Marginal propensities to consume out of non-equity financial wealth, equity wealth and housing wealth}

We now briefly review the discussion of the relative sizes of the MPC out of the three main components of household wealth: non-equity financial wealth, equity wealth and housing wealth. In line with our discussion in two previous sub-sections, there appears to be general agreement that, if the MPC out of wealth differs across these wealth components, then the MPC out of non-equity financial wealth is likely to be highest. However, the relative sizes of the MPCs out of equity wealth and out of housing wealth is more controversial. For both of these wealth components the main variation in their market values comes from the price rather than the volume component. Hence, the sensitivity of consumption to these price movements may depend on how liquid these asset are and how permanent the price changes are expected to be, i.e. whether the mean reversion tendency is associated with asset price changes. The following arguments have been presented in favour of a higher MPC out of housing wealth:

- Since equity prices are more volatile than house prices, households may find it more difficult to assess whether a change in the equity wealth is permanent or temporary. Therefore, they are likely to be more cautious in adapting consumption plans to changes in equity wealth than in housing wealth.

- Since house purchases are generally financed with borrowed money, increases in property values result in a higher net return on this investment than on other assets, implying that the MPC out of housing wealth may be larger than for assets with lower expected returns.

- In most countries housing wealth is more evenly distributed than equity holdings, which are concentrated in the upper tail of income distribution. If, as some studies indicate, the MPC is lower among the richest households, then, at the aggregate level, the wealth effect from housing may be expected to be more important than the effect from equity wealth.

- In some countries, differential taxtreatment of equity holdings and residential property may lower the MPC out of equity wealth because stock holdings have to be retained to receive a more favourable taxtreatment.

On the other hand, a partial equilibrium analysis may suggest a less clear-cut housing wealth effect on consumption because of the dual effects of house prices on non-housing consumption, i.e. a positive wealth effect, which depend on the liquidity of houses, and a negative relative price effect. ${ }^{2}$ Since houses are part of household wealth, changes in their value are expected to have a positive effect on the consumption of homeowners. Conversely, for tenants, an increase in house prices leads to higher rental prices and a negative income impact on their consumption. However, the wealth effect for landlords or pension funds and similar institutional investors owning rental housing has also to be considered. This wealth effect, at least to the extent that the landlords belong to the household sector, neutralises the negative consumption effects of the rent paid by tenants. However, typically a proportion of tenants are also future homeowners, who with limited access to the mortgage market have to increase savings in response to rising house prices in order to be able to purchase a house later. Hence, if

2 See Muellbauer and Lattimore (1995), for a clear exposition of this dual role.
2 WEALTH CHANNEL 
households are divided into house owners (including landlords) and tenants, a positive relation between consumption and house prices would be expected for house owners and a close to zero (slightly negative) relation for tenants. In addition, the wealth effect is the smaller the less liquid the housing property is. According to Maclennan, Muellbauer and Stephens (1998) the perceived liquidity of housing assets varies a lot across Europe. This is due to, among other things, differences in transaction costs (e.g. stamp duties), the collateral role of the assets and inheritance taxes, particularly when housing is sheltered from inheritance taxes, which can be translated into a restriction on resale. Under these circumstances, other things being equal, they conclude:

- The higher the proportion of owneroccupiers and the lower the proportion of households in the rented market, the larger will be the consumption response to a rise in house prices.

- The larger the proportion of rental housing which is owned by pension funds and similar institutional investors, the smaller will be the consumption response to a rise in house prices. The reason is that (future) pensions are rather illiquid component of consumers' portfolios. ${ }^{3}$

\subsection{SOME CONCLUSIONS}

On the basis of the discussion in Section 2 the following conclusions can be drawn:

- The long-run MPC out of different wealth components should be quite stable over time. The main determinants are the length of the planning horizon, the bequest motive and a weighted average of the expected rate of return on wealth (over the planning horizon) and the subjective discount rate.

- Risk aversion associated with uncertainty widens the range of feasible values for the MPC out of wealth $m p c_{W}$. With the plausible values of risk aversion $(1 / \sigma \geq 1) m p c_{W}$ increases with the rate of return $r_{a}$, but the opposite is true, if risk aversion is low, i.e. $0 \leq 1 / \sigma<1$. Hence, low relative risk aversion allows for low values of $m p c_{W}$.

- With typical estimates of risk aversion $(1 \leq 1 / \sigma \leq 3)$, the MPC out of wealth should be above the subjective discount rate.

- Income uncertainty implies that the MPC out of wealth of wealthy consumers may be markedly lower than that of consumers with low wealth. For instance, if equity wealth is concentrated in the upper end of income distribution, then at the aggregate level the MPC out of equity wealth may be lower than the MPC out of other wealth components.

- The MPC out of wealth may differ across wealth components as a reflection of differences in liquidity properties and bequest motives associated with them. These cross asset differences may be strongly affected by developments in collateral markets and taxation.

- The transmission of asset price changes to consumption is largely determined by how permanent asset price changes are expected to be. Changes that are expected to be transitory have less effect on consumption. This issue is linked to the predictability of equity market returns.

- If the MPC out of wealth differs across wealth components, then the MPC out of non-equity financial wealth is likely to be highest. However, there are diverging views regarding the relative sizes of the MPCs out of equity wealth and out of housing wealth.

3 This is in line with Poterba (2000), who argued that pension funds and houses are long-term "locked" assets, the MPC out of which is lower than out of "unlocked" assets. 
3

\section{HOUSEHOLD WEALTH: A STATISTICAL} REVIEW

To give statistical background to our international comparison of estimated wealth and asset market effects on consumption we first make an international comparison of household wealth and wealth composition. The theoretical review in Section 2 revealed that the composition of wealth, its distribution across income classes and age groups, and demographics may have importance in the international comparison of wealth effects. Therefore, in sub-section 3.1, we first compare household wealth and its decomposition into financial and housing wealth across countries. ${ }^{4}$ Then the decomposition of financial wealth across counties is presented in sub-section 3.2. Since planning horizons and bequest motives can vary across consumers and across wealth components, sub-section 3.3 reports crosscountry comparisons of wealth distributions across income classes and age groups. Special attention is also paid to housing wealth and house prices and to equity wealth.

\section{I DECOMPOSITION OF HOUSEHOLD WEALTH INTO FINANCIAL AND HOUSING WEALTH}

Table 3.1 reports the decomposition of total household wealth into its two main components, i.e. financial and housing wealth, in 1995 and 2000 for six EU countries and the
United States. ${ }^{5}$ Each wealth component is presented as a percentage of GDP and a percentage of total wealth. As can be seen, the ratios to GDP of both total household wealth and its components vary considerably both over time and across countries. In 2000 total household wealth was highest in Spain, at $521 \%$ of GDP, and lowest in Germany, at $371 \%$ of GDP.

Regarding the composition of total household wealth, financial wealth dominates in the Netherlands, the United Kingdom and the United States with financial wealth shares above $60 \%$. In 2000 the financial assets to GDP ratio was highest in the United States (341\%), the United Kingdom and the Netherlands (both around $300 \%$ ). In continental Europe this ratio was lower: somewhat above $200 \%$ in France and Italy and somewhat below $200 \%$ in Spain and Germany. In the period 1995-2000 financial wealth rose as a percentage of GDP in all countries as a result of strong equity price increases. The increase in this ratio was particularly strong in France (69 percentage points) and lowest in Germany (31 percentage points).

4 For a comprehensive presentation of EU housing markets, see ECB (2003).

5 The statistical source for financial assets is same as in Table 3.2. Housing wealth is drawn from OECD sources except for Spain and the Netherlands, which is from Arnold et al. (2002). Therefore, the figures in Table 3.1 are not fully comparable and should be only taken as indicative.

\section{Table 3.I Total household wealth decomposed into financial and housing wealth}

\begin{tabular}{|c|c|c|c|c|c|c|c|c|c|c|c|c|c|c|}
\hline & \multicolumn{2}{|c|}{ France } & \multicolumn{2}{|c|}{ Germany } & \multicolumn{2}{|c|}{ Italy } & \multicolumn{2}{|c|}{ Spain } & \multicolumn{2}{|c|}{ Netherlands } & \multicolumn{2}{|c|}{$\begin{array}{c}\text { United } \\
\text { Kingdom }\end{array}$} & \multicolumn{2}{|c|}{$\begin{array}{l}\text { United } \\
\text { States }\end{array}$} \\
\hline & 1995 & 2000 & 1995 & 2000 & 1995 & 2000 & 1995 & 2000 & 1995 & 2000 & 1995 & 2000 & 1995 & 2000 \\
\hline \multicolumn{15}{|c|}{ Financial assets } \\
\hline$\%$ of GDP & 165 & 234 & 149 & 180 & 189 & 227 & 150 & 187 & 254 & 297 & 261 & 299 & 292 & 341 \\
\hline$\%$ of wealth & 50 & 53 & 44 & 49 & 45 & 51 & 33 & 36 & 69 & 62 & 64 & 61 & 71 & 73 \\
\hline \multicolumn{15}{|c|}{ Housing wealth } \\
\hline$\%$ of GDP & 170 & 206 & 191 & 191 & 234 & 220 & 298 & 334 & 112 & 182 & 146 & 191 & 120 & 130 \\
\hline$\%$ of wealth & 50 & 47 & 56 & 51 & 55 & 49 & 67 & 64 & 31 & 38 & 36 & 39 & 29 & 27 \\
\hline \multicolumn{15}{|l|}{ Total wealth } \\
\hline$\%$ of GDP & 335 & 440 & 340 & 371 & 423 & 447 & 448 & 521 & 366 & 479 & 407 & 490 & 412 & 471 \\
\hline$\%$ of wealth & 100 & 100 & 100 & 100 & 100 & 100 & 100 & 100 & 100 & 100 & 100 & 100 & 100 & 100 \\
\hline
\end{tabular}


However, in spite of this development housing wealth continues to play an important role in all countries but, especially, in France, Germany, Italy and Spain where the housing wealth share is close to or above $50 \%$. Reflecting crosscountry differences in house price developments, the ratio of housing wealth to GDP and the share of housing in total wealth decreased in Italy and Germany by about 5 percentage points in 1995-2000. In all other countries, real house prices rose, increasing the ratio of housing wealth to GDP. In the United Kingdom house prices rose so much that the share of housing in total household wealth also increased. Hence, housing prices appear to be markedly less synchronised and their volatility varies more across countries than is the case with stock prices.

\section{2 DECOMPOSITION OF HOUSEHOLD FINANCIAL WEALTH INTO COMPONENTS6}

Over the past decade financial markets have moved towards greater integration as well as product innovation. In Europe, the removal of capital controls, the privatisation of public utilities and recent pension reforms are some of the policy interventions which have transformed financial markets and consequently affected the allocation of household wealth.
This can be seen in Table 3.2, which shows the allocation of the financial wealth of households among its six main components in 1995 and 2000 in the same countries as in Table 3.1.7 Pension funds are the major factor in explaining the differences in the financial wealth to GDP ratio among the three countries with the highest ratio, i.e. the United States, the United Kingdom and the Netherlands, where the financing of pensions is mainly fund-based, and four countries with markedly lower ratios, i.e. France, Germany, Italy and Spain, where the financing of pensions is based mainly on "pay-as-you-go".

The share of stock market related wealth (stocks plus mutual funds in Table 3.2) is highest in the United States (46\%) and it is almost as high in Italy and Spain (about $43.5 \%$ in 2000). All in all, the increase in the share of this risky wealth component was notably faster in France, Germany, Italy, and Spain than in the Netherlands, the United Kingdom and the United States during the later half of 1990s.

6 This section is mainly based on Babeau and Sbano (2002) and Guiso et al. (2002)

7 The "household" in Table 3.2 includes non-profit institutions serving households (e.g. churches, consumer associations, labour unions) and the self-employed.

\begin{tabular}{|c|c|c|c|c|c|c|c|c|c|c|c|c|c|c|}
\hline \multicolumn{15}{|c|}{ (as \% of financial assets, unless otherwise indicated) } \\
\hline & \multicolumn{2}{|c|}{ France } & \multicolumn{2}{|c|}{ Germany } & \multicolumn{2}{|c|}{ Italy } & \multicolumn{2}{|c|}{ Spain } & \multicolumn{2}{|c|}{ Netherlands } & \multicolumn{2}{|c|}{$\begin{array}{l}\text { United } \\
\text { Kingdom }\end{array}$} & \multicolumn{2}{|c|}{$\begin{array}{l}\text { United } \\
\text { States }\end{array}$} \\
\hline & 1995 & 2000 & 1995 & 2000 & 1995 & 2000 & 1995 & 2000 & 1995 & 2000 & 1995 & 2000 & 1995 & 2000 \\
\hline Currency and deposits & 39.1 & 30.4 & 41.9 & 36.2 & 40.1 & 24.1 & 51.8 & 36.2 & 22.5 & 18.1 & 24.2 & 22.2 & 14.1 & 11.1 \\
\hline $\begin{array}{l}\text { Securities other } \\
\text { than stocks }\end{array}$ & 5.5 & 2.7 & 13.5 & 10.1 & 30.7 & 18.7 & 4.2 & 1.9 & 3.3 & 2.3 & 1.6 & 1.3 & 9.4 & 6.4 \\
\hline Stocks & 15.8 & 24.8 & 10.9 & 15.6 & 14.5 & 27.6 & 19.0 & 33.7 & 15.4 & 16.8 & 15.7 & 17.4 & 32.0 & 33.1 \\
\hline Mutual funds & 8.6 & 9.0 & 5.9 & 10.5 & 3.1 & 15.9 & 6.2 & 9.9 & 3.6 & 5.5 & 3.8 & 5.5 & 9.6 & 12.9 \\
\hline Life insurance & 17.9 & 23.3 & 11.8 & 13.6 & 3.3 & 6.2 & 4.5 & 6.2 & 15.3 & 15.4 & 27.7 & 27.5 & 7.1 & 7.1 \\
\hline Pension funds & 1.8 & 1.5 & 5.6 & 5.2 & 0.8 & 1.2 & 4.5 & 5.3 & 35.5 & 37.7 & 22.3 & 22.1 & 23.4 & 23.8 \\
\hline $\begin{array}{l}\text { Financial assets } \\
\text { as } \% \text { of GDP }\end{array}$ & 165 & 234 & 149 & 180 & 189 & 227 & n.a. & 187 & n.a. & 297 & 261 & 299 & 292 & 341 \\
\hline
\end{tabular}


The shift towards riskier assets is divided differently across countries between direct holdings of equities and investments in mutual funds. The portion of wealth held in mutual funds is rising everywhere, but especially in Italy and Germany. The tendency to take greater risks is also apparent in the proportion of equity funds within investment funds as a whole: they have increased their share in five of the six countries.

By contrast, euro area countries have experienced a generalised decline in banking intermediation. This trend is particularly noticeable in Spain, Italy and France and to a lesser extent in Germany. The decline has less of an impact on sight/overnight deposits than on term and savings deposits. There has also been a sharp decline in the portion of interestbearing securities (bonds and loans), mainly due to the decline in long-term interest rates and efforts to improve public finances. This trend is particularly visible in Italy, where the share of such investments was above $30 \%$ in the early 1990 s (the highest ratio in the euro area) and fell to $18.7 \%$ in 2000 .

Household claims on insurance companies grew over the period considered in France and, to lesser extent, in Germany, Italy and Spain. In

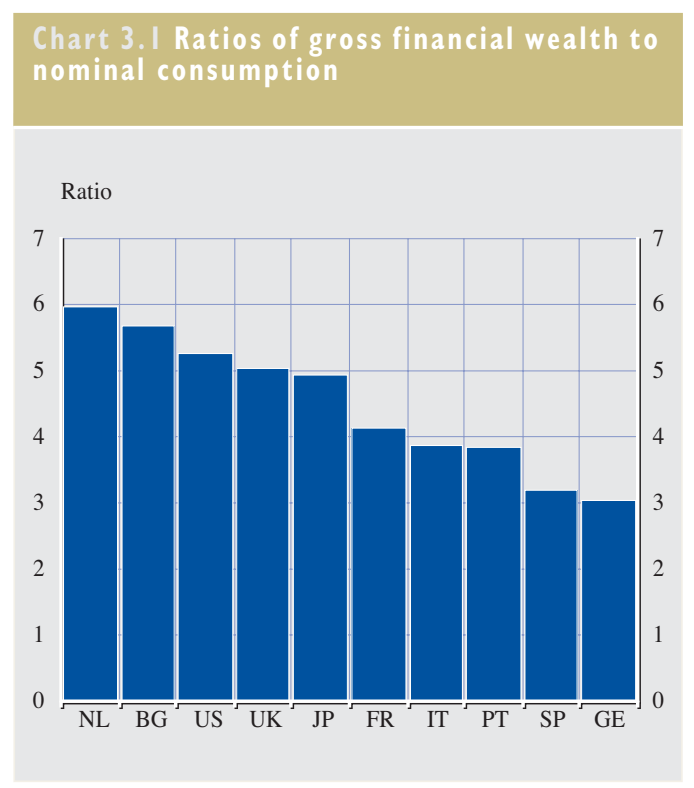

the United Kingdom and the Netherlands, where life insurance assets were already very high at the beginning of the period, they remained roughly stable. For saving purposes, life insurance policies are often perceived to be low risk. However this changed recently with the spectacular growth of unit-linked policies in Italy, France and Spain. Since the late 1980s such policies have already played an important role in the United Kingdom and the Netherlands. Only in Germany was there no evidence of this move towards riskier assets.

Available financial wealth data indicate surprisingly large variations across countries in the ratio of wealth to consumption. Based on national sources, Chart 3.1 shows that the ratio of total wealth to consumption is highest in the Netherlands, at around twice the level in Germany, where this ratio is lowest. ${ }^{8}$ If the MPC out of wealth were equal across countries, then relation (2.2) would imply that the wealth elasticity of consumption in the Netherlands would also be around twice that of Germany. Although the role of pension funds explains a large part of these cross-country differences in the ratio of financial wealth to consumption, remaining differences are still important and difficult to explain. It may be that, rather than true differences, they reflect different methods of measuring wealth and, therefore, problems of data comparability. We return this issue in the sub-section 4.4 .

\subsection{EQUITY WEALTH EFFECT, INCOME DISTRIBUTION AND DEMOGRAPHICS}

In Section 2 we showed that the distribution of wealth may affect aggregate MPCs out of different wealth components. Coupled with demographic factors, this may help explain cross-country differences in wealth effects. In this section we study the distribution of wealth, especially equity wealth, across income earners and age cohorts in different countries.

8 Financial wealth data in Tables 3.1 and 3.2 are not fully compatible with data used in Chart 3.1. 


\section{Table 3.3 Percentage of households with direct equity holdings, by income group}

\begin{tabular}{|c|c|c|c|c|c|c|}
\hline France & & & & & & All \\
\hline Income group (EUR) & $0-1500$ & $1500-2300$ & $2300-3050$ & $3050-3800$ & $3800-$ & \\
\hline Income group by percentile & $0-32$ & $32-65$ & $65-83$ & $83-91$ & $91-100$ & \\
\hline \multicolumn{7}{|l|}{ Percentage owning equity: } \\
\hline in 1997 & 6.1 & 10.1 & 15.5 & 19.1 & 32.6 & 12.0 \\
\hline in 2000 & 7.4 & 11.2 & 14.3 & 21.1 & 31.4 & 12.7 \\
\hline \multicolumn{7}{|l|}{ Germany } \\
\hline Income group (EUR) & $0-1300$ & $1300-2050$ & $2050-3050$ & $3050-4100$ & $4100-$ & \\
\hline Income group by percentile & $0-21$ & $21-51$ & $51-84$ & $84-93$ & $93-100$ & \\
\hline \multicolumn{7}{|l|}{ Percentage owning equity: } \\
\hline in 1997 & 1.7 & 3.9 & 8.3 & 14.6 & 18.7 & 6.2 \\
\hline in 2000 & 3.0 & 5.8 & 11.4 & 20.4 & 25.9 & 9.8 \\
\hline \multicolumn{7}{|l|}{ Italy } \\
\hline Income group (EUR) & $0-850$ & $850-1700$ & $1700-2600$ & $2600-3450$ & $3450-$ & \\
\hline Income group by percentile & $0-18$ & $18-51$ & $51-74$ & $74-87$ & $87-100$ & \\
\hline \multicolumn{7}{|l|}{ Percentage owning equity: } \\
\hline in 1995 & 0.2 & 2.0 & 5.0 & 10.3 & 21.5 & 5.0 \\
\hline in 1998 & 0.6 & 2.4 & 5.7 & 11.9 & 31.7 & 7.8 \\
\hline \multicolumn{7}{|l|}{ United Kingdom } \\
\hline Income group by percentile & $0-25$ & $25-50$ & $50-75$ & $75-100$ & & \\
\hline \multicolumn{7}{|l|}{ Percentage owning equity: } \\
\hline in 1993 & 8.2 & 14.8 & 27.0 & 41.3 & & 22.8 \\
\hline in 1996 & 13.4 & 15.6 & 26.5 & 37.9 & & 23.3 \\
\hline \multicolumn{7}{|l|}{ United States } \\
\hline Income group (USD) & $0-850$ & $850-2100$ & $2100-4150$ & $4150-8350$ & $8350-$ & \\
\hline Income group by percentile & $0-13$ & $13-37$ & $37-66$ & $66-91$ & $91-100$ & \\
\hline \multicolumn{7}{|l|}{ Percentage owning equity: } \\
\hline in 1995 & 2.3 & 8.4 & 13.9 & 24.7 & 43.6 & 15.2 \\
\hline in 1998 & 3.8 & 7.2 & 17.7 & 27.7 & 56.6 & 19.2 \\
\hline
\end{tabular}

Sources: "Equity wealth and consumption - the experience of Germany, France and Italy in an international context", Bank of England Quarterly Bulletin, Spring 2002, p. 81. The original sources are provided there.

Notes: The table shows the proportion of each income group holding direct equities excluding mutual funds. Numbers are not fully comparable across countries due to different definitions of households.

Table 3.3 reports recent equity holdings across different income brackets in Germany, France, Italy, the United Kingdom and the United States. Table 3.4 presents the distribution of equity ownership across different age groups in the same countries.

The last column of both tables reveals that share ownership is much more concentrated in the three euro area countries than in the United States and the United Kingdom. While in the United States around $20 \%$ of the population own shares, this proportion falls to around $8 \%$ in Italy (in 1998), 10\% in Germany (in 2000) and $13 \%$ in France (in 2000). ${ }^{9}$ In the United Kingdom, more than $20 \%$ of the population owns shares.
Common features across countries are that (1) the percentage of households holding equities has increased and (2) the share of equity owners in each income bracket is positively related to the income level. In Table 3.3 the proportion of households holding shares in the highest income bracket is between 2 and 4 times larger than the average proportion in the population. The proportion of share ownership in high income brackets is larger in the United States

9 Figures reported here are not fully comparable across countries because of differences in the definition of households. In particular, the figures for Germany may underestimate the percentage of households holding equities as they refer to the population above 14 years of age, while for Italy and the United States a household is defined as an economic unit that includes more than one person on average. 


\section{Table 3.4 Percentage of households with direct equity holdings, by age group}

\begin{tabular}{|c|c|c|c|c|c|c|c|}
\hline France & & & & & & & All \\
\hline Age group & $15-24$ & $25-34$ & $35-44$ & $45-54$ & $55-64$ & $65-$ & \\
\hline Percentage of population & 13.0 & 14.5 & 14.6 & 13.9 & 9.2 & 15.9 & \\
\hline \multicolumn{8}{|l|}{ Percentage owning equity: } \\
\hline in 1997 & 3.7 & 7.9 & 10.2 & 14.6 & 17.9 & 19.2 & 12.0 \\
\hline in 2000 & 3.3 & 9.1 & 11.6 & 17.6 & 16.9 & 18.3 & 12.7 \\
\hline \multicolumn{8}{|l|}{ Germany } \\
\hline Age group & 14-19 & $20-29$ & $30-39$ & $40-49$ & $50-59$ & $60-$ & \\
\hline Percentage of population & 6.7 & 11.9 & 17.2 & 14.5 & 12.2 & 23.0 & \\
\hline \multicolumn{8}{|l|}{ Percentage owning equity: } \\
\hline in 1997 & 1.0 & 4.4 & 7.3 & 8.7 & 8.7 & 4.9 & 6.2 \\
\hline in 2000 & 2.4 & 7.6 & 13.5 & 11.7 & 13.1 & 7.2 & 9.2 \\
\hline \multicolumn{8}{|l|}{ Italy } \\
\hline Age group & $15-30$ & $31-40$ & $41-50$ & $51-65$ & $65-$ & & \\
\hline Percentage of population & 22.2 & 15.5 & 13.5 & 17.9 & 16.3 & & \\
\hline \multicolumn{8}{|l|}{ Percentage owning equity: } \\
\hline in 1995 & 2.1 & 5.7 & 5.6 & 6.6 & 2.9 & & 5.0 \\
\hline in 1998 & 3.9 & 9.8 & 7.9 & 9.5 & 5.5 & & 7.8 \\
\hline \multicolumn{8}{|l|}{ United Kingdom } \\
\hline Age group & $25-34$ & $35-49$ & $50-64$ & $65-$ & & & \\
\hline Percentage of population & 16.0 & 20.7 & 15.6 & 15.7 & & & \\
\hline \multicolumn{8}{|l|}{ Percentage owning equity: } \\
\hline in 1993 & 12.8 & 24.1 & 30.4 & 24.7 & & & n.a. \\
\hline in 1996 & 12.9 & 21.6 & 30.2 & 31.2 & & & n.a. \\
\hline \multicolumn{8}{|l|}{ United States } \\
\hline Age group & $0-34$ & $35-44$ & $45-54$ & $55-64$ & $65-74$ & $75-$ & \\
\hline Percentage of population & 23.3 & 23.3 & 19.2 & 12.8 & 11.2 & 10.2 & \\
\hline \multicolumn{8}{|l|}{ Percentage owning equity: } \\
\hline in 1995 & 10.8 & 14.6 & 17.7 & 15.0 & 18.6 & 19.7 & 15.2 \\
\hline in 1998 & 13.1 & 18.9 & 22.6 & 25.0 & 21.0 & 18.0 & 19.2 \\
\hline
\end{tabular}

Sources: "Equity wealth and consumption - the experience of Germany, France and Italy in an international context", Bank of England Quarterly Bulletin, Spring 2002, p. 81. The original sources are provided there.

Notes: The table shows the proportion of each age group holding equities directly, excluding mutual funds. Numbers are not fully comparable across countries due to different definitions of households. and the United Kingdom than in the three euro area countries, although in this respect the differences between countries appear less marked than for the population averages. In addition, Table 3.3 shows that the percentage of middle-to-low income earners holding shares is larger in the United States and the United Kingdom than in the euro area countries. If coupled with the higher MPC out of wealth of the poor relative to the wealthy, this may justify, at least qualitatively, a higher MPC out of equity wealth in the United Kingdom and the United States than in Germany, France and Italy.
Table 3.4 shows that equity ownership is more evenly distributed across age groups than across income brackets, except for the youngest age group. However, a positive relation between equity holdings and age is apparent, especially, in the United Kingdom and the United States. In Germany and Italy this relation turns to negative among retired age groups. Therefore, if the MPC out of wealth is higher for older generations, reflecting a shorter planning horizon, then this may also justify a higher MPC out of equity wealth in the United States and the United Kingdom than in Germany, France and Italy. 
macroeconomic counterparts. However, micro-level studies provide a useful check on whether theories of the wealth effect are

This section reviews cross-country empirical evidence of wealth effects on consumption. Sub-section 4.1 presents evidence based on micro-data studies, which are most closely linked to data characteristics examined in Section 3. The merit of the micro-data approach is its ability to separate direct and indirect wealth effects. Sub-section 4.2 presents MPCs out of wealth in theory-based calibrated multi-country models. Sub-section 4.3.1 discusses MPC out of wealth estimates based on time-series estimation of the deep parameters of theory-based consumption functions. In sub-section 4.3.2 we review results based on direct (unconstrained) aggregate time-series estimations. Although the available evidence mostly suggest an important wealth channel, our general conclusion is that the variation of MPC out of wealth estimates across studies, across countries and across estimation methods is disconcertingly large. Such differences in typical MPC out of wealth estimates across countries are implausible in the light of economic theory. In sub-section 4.4, after a critical assessment of the wealth data used in cross-country comparisons, we propose that incomparable measures of wealth across countries and across studies may be an important source of differences in MPC out of wealth estimates. To reduce these problems in wealth data, sub-section 4.5 presents some recent estimation results based on dynamic panel approach. Sub-section 4.6 concludes.

\section{I MICRO DATA EVIDENCE}

This section briefly surveys the evidence from micro-level studies. Unfortunately most of these studies are limited to US data. Recent exceptions are studies by Paiella (2003) and Guiso, Paiella and Visco (2004) using Italian data. In addition, all these studies use datasets with limited coverage of consumption and/or asset holdings. Thus, key parameter estimates may not always be directly comparable to their

consistent with individual behaviour.

There are a large number of micro-data studies of various aspects of the wealth effect and, as is often the case with such literature, these studies have frequently come to different conclusions. However, a reasonable interpretation of these studies is that they tend to back up the macroeconomic evidence on the role of the wealth effect. ${ }^{10}$

A number of studies of have analysed the relationship between equity wealth and consumption within the consumption-based capital asset pricing model (C-CAPM). For example Mankiw and Zeldes (1990), Attanasio, Banks and Tanner (1998), Vissing-Jørgensen, (1999), and Brav, Constantinides and Geczy (1999) find that the spending of stockholders is more highly correlated with stock market returns than that of non-stockholders, which supports a direct effect. Less positively, Parker (1999b) and Juster, Lupton, Smith and Stafford (1999) both find that spending responds to wealth at the household level, but neither paper can pinpoint responses within the time frame necessary to explain the macro relationship.

A comprehensive study by Maki and Palumbo (2001) provides important evidence in favour of the wealth effect on US consumer spending during the 1990s. Using data from the Survey of Consumer Finances, they find that the groups of families whose portfolios were boosted most by the exceptional stock market performance over the latter half of the 1990s are the same groups whose net saving flows declined most sharply between 1995 and 2000.

10 Of course, one can find some evidence to the contrary. For example, Starr-McCluer's (2000) analysis of qualitative evidence from the University of Michigan's SRC Survey of Consumers suggests that the spending of stockholders is only modestly affected by changes in wealth, and Otto (1999) finds that the correlation between stock prices and consumer sentiment does not vary by stock ownership. 
Families who owned relatively modest amounts of equity wealth - the vast majority of US households - experienced relatively small gains in net worth to income ratios over the 1990s and continued to save at about the same steady pace over the decade. In addition, Maki and Palumbo's study verifies that essentially all of the increased spending apparent in the aggregate data can be attributed to an increase in the MPC out of income of the richest US households. Finally, they present new econometric estimates of the MPC out of household net worth based on cohort-level time-series data that fall in the same range -3 to 5 cents per dollar - as typical macroeconomic estimates (although somewhat lower than the preferred estimates in Table 2 above). These econometric results bolster the conclusion that the direct wealth effect on household spending is of the right size to explain the sharp decline in the aggregate saving rate observed in the 1990 s.

These results are also compatible with those of Dynan and Maki (2001) who use data from the Consumer Expenditure Survey and imputed values of equity holdings to estimate the effects of stock market wealth on consumption. They find that direct wealth effects begin to show up relatively quickly and continue to boost consumption growth for a number of quarters, which is in line with aggregate estimates. In contrast to many earlier studies, they find that the indirect wealth channel is not an important determinant of consumption growth. This study also reports estimates of the MPC out of stock market wealth of between 5 and 15 cents per dollar, but notes that its sample excludes highincome households likely to have lower MPCs. Indeed, both Parker (1999a) and Dynan et al. (2000) show that the average propensity to consume declines with permanent income. ${ }^{11}$

Evidence found by Paiella (2003) and, especially, by Guiso, Paiella and Visco (2004) for Italy, resemble in many respects the US evidence described above, although the estimated size of the wealth effect is smaller than typical US estimates. The estimates of
MPC were around 2 cents per euro out of total wealth and out of housing wealth, respectively, and slightly below 4 cents per euro out of net financial wealth. However, when dividing their data into homeowners and tenants Guiso, Paiella and Visco (2004) found that the MPC out of housing wealth (excluding current period capital gains on real estate) and the MPC out of capital gains on real estate were 2 and 3.5 cents per euro, respectively. For tenants they did not find any statistically significant relation between consumption and capital gains on real estate (or house prices), but the estimated MPC out of net wealth was in the range of 3.7 to 6.2 cents per euro. All these results support direct effects from wealth and its components on consumption. Regarding equity wealth effects on consumption, both studies found hardly any evidence for the MPC out of equity wealth. However, it is quite likely that this result contains a downward bias, because households at the top of the income and wealth distribution were underrepresented in the survey data.

\subsection{THE MPC OUT OF WEALTH IN SOME CALIBRATED THEORY-BASED MODELS}

In theoretically-founded models, such as the IMF's MULTIMOD, deep structural parameters such as the rates of return and the planning horizon are calibrated. The calibrated MPCs out of wealth of MULTIMOD provide a theory-consistent guide to reasonable benchmark for the MPC out of wealth to be expected from empirical research.

Chart 4.1 shows the MPC out of wealth implied by MULTIMOD. These MPCs out of wealth are based on the Mark III version, as this provides separate MPCs out of wealth for the countries of the euro area. These MPCs out of wealth range between 5.4 and 8.2 per cent. The highest values are those for the United States and

11 It is worth noting, however, that while the average propensity to consume depends on wealth, this does not imply that the same must be true for the MPC out of wealth.
4 ASSET PRICE

EFFECTS VIA

THE WEALTH

CHANNEL:

EMPIRICAL

EVIDENCE 


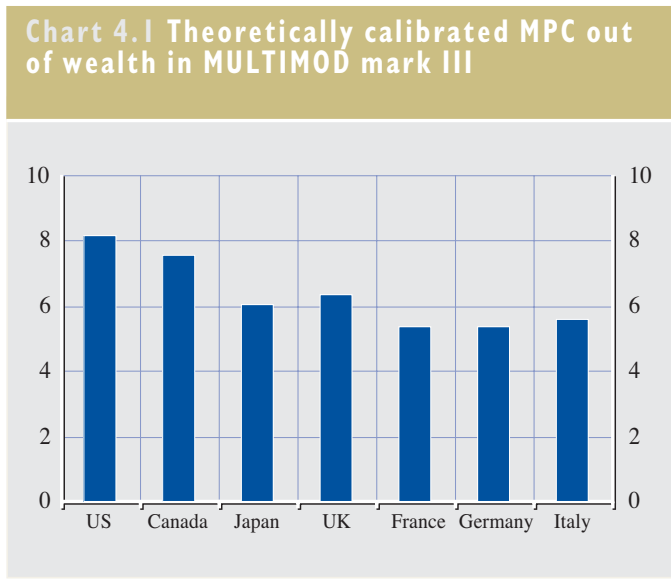

Canada, followed closely by those for the United Kingdom and Japan; the values for the euro area economies are somewhat below 6 . Overall, the MPC out of wealth tends to be quite similar across countries. In fact, three of the four parameters determining the MPC out of wealth in MULTIMOD - the intertemporal elasticity of substitution in consumption, the real interest rate, the probability of death - are the same across countries in the long run, as a result of calibration or pooled estimation (see Faruquee, Isard, Laxton, Prasad and Turtelboom (1998)).

\subsection{AGGREGATE TIME SERIES ESTIMATES OF MPC OUT OF WEALTH:}

The following sub-section reviews estimates based on time-series estimation of the deep parameters of theory-based consumption functions. Sub-section 4.3.2 examines the evidence based on aggregate time series estimation without theory-based parameter constraints.

\subsection{MPC OUT OF WEALTH BASED ON THE ESTIMATED DEEP PARAMETERS OF THE CONSUMPTION FUNCTION}

Not many studies estimate the consumption function explicitly in terms of deep parameters. Some exceptions are Hayashi (1982b), Darby et al. (1999), Sefton and in't Veld (1999),
Fuhrer (2000) and Willman (2003). Through quasi-differing human wealth in the stochastic permanent income hypothesis consumption function, Hayashi (1982b) estimates the solved-out consumption function (1982) for the United States and Darby et al. (1999) for the United Kingdom. Sefton and in't Veld (1999) apply the Blanchard (1985) overlapping generations model with positive probability of death. Willman (2003), in the framework of the overlapping generation model, also account for habit formation. Hayashi (1982b) and Darby et al. (1999) directly estimate the MPC out of wealth. In Sefton and in't Veld (1999) and in Willman (2003) the estimated length of planning horizon (probability of death) is the crucial determinant of the MPC out of wealth, as shown by equation (2.6).

Hayashi's (1982b) estimates of MPC out of wealth were in the theoretically reasonable range of 3.3 to 8.6 with the preferred point estimate at 6.8 cents per dollar, which is very close to the Darby et al. (1999) point estimate of 7.1 pence per pound for the UK. In Sefton and in't Veld (1999) estimates of MPC out of wealth were in the range of 3 to 16 cents per dollar for the United States, 9 cents per dollar for Canada, 6 to 7 pence per pound for the United Kingdom and 4 to 9 pfennigs per Deutsche Mark for Germany. Willman (2003) estimated the consumption function using aggregated quarterly euro area data and found an MPC out of wealth in the range of 7-10 cents per euro for the planning horizon in the range of 12-32 years. Estimates for the habit persistence parameter defining the adjustment speed from shocks to consumption was in the range of 0.7 to 0.8. Apart from Sefton and in't Veld's outlying estimates in the upper limit of the range, the ranges of these estimates were quite reasonable and broadly in line with those calibrated for MULTIMOD. Further, these results indicate no clear evidence for the MPC out of wealth being lower in continental Europe than in the English-speaking countries. 


\subsubsection{AGGREGATE TIME SERIES ESTIMATE OF MPC OUT OF WEALTH: DIRECT DATA-BASED APPROACH}

This sub-section reviews the available evidence on the long-long run effects of wealth and its components on consumption. First we review some recent comparative international studies on the long-run effects of wealth and its components on consumption. Then we present estimation results based on country-specific studies.

4.3.2.1 Evidence based on cross-country studies International comparisons include: Ludwig and Sløk (2002), Bertaut (2002), Boone et al. (1998), Labhard et al. (2005) Case et al. (2001) and Edison and Sløk (2001).
Ludwig and Sløk (2002) use a panel data of 16 OECD countries, where countries are classified (on ad hoc bases) as market-based and bank-based economies. As shown in Table 4.2, pooled results for market-based economies (Australia, Canada, the Netherlands, Ireland, Sweden, the United Kingdom and the United States) imply that a $10 \%$ increase in equity prices increases long-run consumption by nearly $1 \%$, while in bank-based economies (Finland, France, Germany, Italy, Japan, Norway and Spain) the estimated elasticity is much smaller at $0.4 \%$.

Ludwig and Sløk provide MPCs out of equity wealth for a subset of countries. Reported MPCs are in a range of between 1.4 and 4.9,

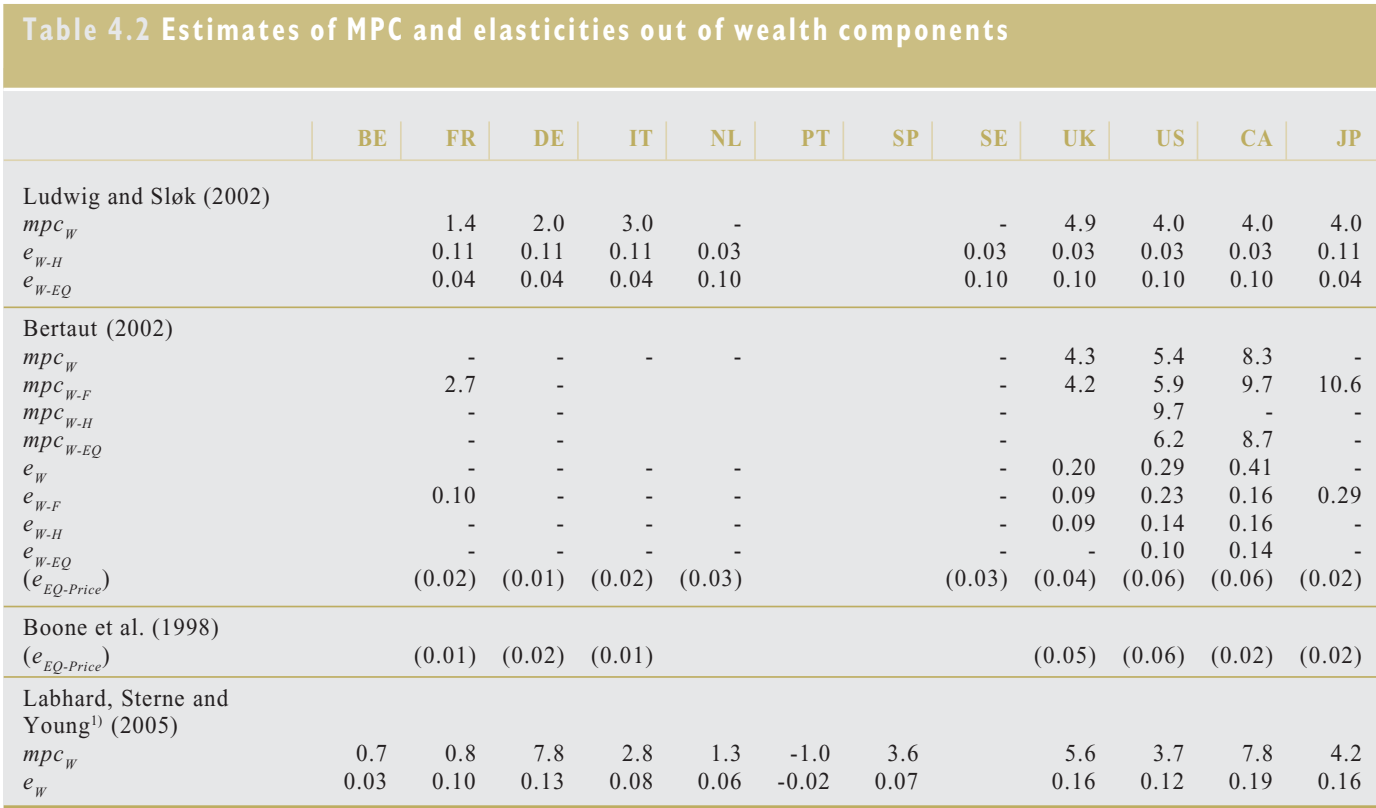

Legend: $\mathrm{mpc}_{\mathrm{W}-\mathrm{j}}$ and elasticity, $\mathrm{e}_{\mathrm{w}-\mathrm{i}}$ out of the wealth component $\mathrm{j}$, with $\mathrm{j}=$ equities (EQ), financial wealth (F), non-equities (N-EQ) and housing $(\mathrm{H})$.

1) Figures are averages of the estimates given by Ludvigson, Steindel and Lettau (2002) using 5 and 6-variable VARs in levels and in differences. 
broadly consistent with the lifetime budget constraint discussed in Section 2. Amongst European countries, they are lowest for Germany (2.0) and France (1.4) and highest for the United Kingdom (4.9) and Italy (3.0). There are few indications as to why the MPCs vary across countries. This appears to be a result of the pooled estimation techniques, which fixes the elasticity, instead of the MPC out of wealth components $m p c_{W-j}$, to be equal within groups. Therefore the common elasticity estimated for France and Italy, for instance, inevitably implies an MPC out of equity wealth $m p c_{W-E Q}$ in France that is half that in Italy, since the stock market capitalisation ratio in France is twice that in Italy. Ludwig and Sløk's results may therefore be more useful for comparing MPCs across groups than across countries within the groups. Ludwig and Sløk find clear evidence that the impact of changes in stock prices on consumption is bigger in economies with market-based financial systems than in economies with bank-based financial systems. This impact from stock markets to consumption has increased over time for both groups of countries.

The effect of housing prices on consumption has also become more important over time. The authors consider this change to be a striking evidence for relevant changes in the mortgage markets. In the sample period 1985-2000 the effect of housing prices is significantly positive and the estimated elasticity is about twice as large as the elasticity of stock market prices for the combined sample of all countries and for the group of market-based economies. Ludwig and Sløk do not provide an implied MPC out of housing wealth $m p c_{W-H}$. Utilising the information contained in Table 3.1 and Chart 4.1, the corresponding MPC out of housing wealth would be around 7.5 cents per euro for Germany and around 5 cents per euro for France and Italy. In market-based economies these estimates would be smaller, i.e. 1.3 cents per euro for the Netherlands, 1.7 pence per pound for the United Kingdom and 2 cents per dollar for the United States. As well as grouping countries according to financial structure Ludwig and Sløk also group their data according to home-ownership rates. They find that an increase in the home-ownership rate increases the probability that a positive wealth effect will outweigh negative income and substitution effects on consumption. This result supports our discussion in sub-section 4.3.2.2.

Bertaut (2002) estimates individual country regressions for various forms of wealth. He used both stock price data and disaggregated household wealth data, to the extent available. Accordingly, the estimations based on proper wealth data cover fewer countries, i.e. France, the United Kingdom, the United States, Canada and Japan. The MPC out of wealth estimates for wealth and its components are roughly in line with those of Ludwig and Sløk (2001), being slightly lower for the United Kingdom (4.3 pence per pound), but higher for the United States ( 5.4 cents per dollar), France (2.7 cents per euro) and, especially, Canada ( 8.3 cents per dollar) and Japan (10.6 yen per 100 yen). The United States was the only country for which it was possible to disaggregate wealth into equity and housing components. The estimated MPC out of housing wealth was markedly higher ( 9.7 cents per dollar) than that estimated by Ludwig and Sløk (2001) and also higher than that out of equity wealth (6.2 cents per dollar). Reducedform equations using equity prices gave markedly lower elasticities for equity wealth than those of Ludwig and Sløk (2001) (see figures in brackets in Table 4.2). Even in the United States and Canada, where adequate disaggregated wealth data were available, these reduced-form estimates imply markedly smaller impacts of changes in equity wealth on consumption than corresponding estimates based on wealth data. This evidence suggests that estimates based on stock price data contain a downward bias.

Boone et al. (1998) estimates long-run consumption function for seven major OECD countries (the United States, Japan, Canada, Germany, France, Italy and the United Kingdom). Due to the lack of adequate wealth 


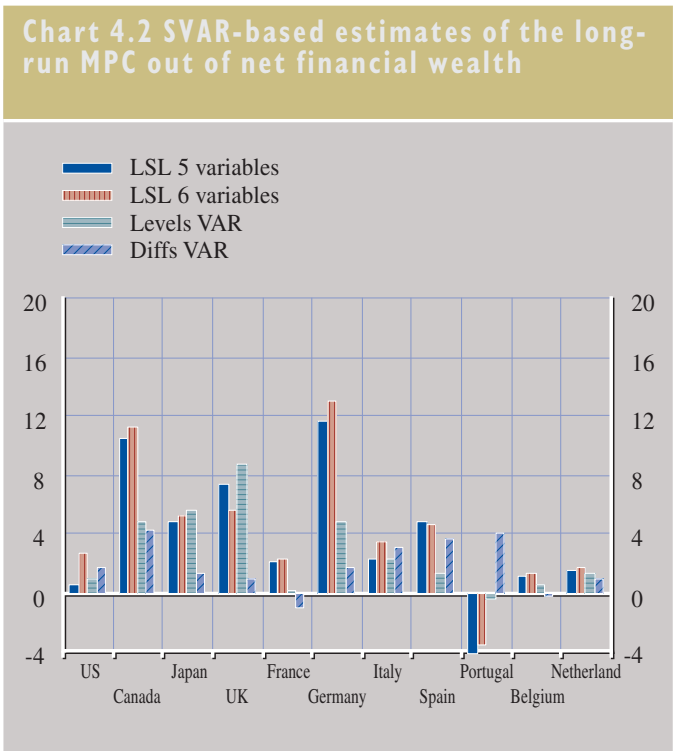

data they also use only equity price and housing price data in estimating consumption responses to changes in asset values. These estimation results are well in line with corresponding estimation results presented by Bertaut (2002). Accordingly, they may contain a downward bias.

Labhard, Sterne and Young (2005) presents estimates of the MPC out of wealth using estimates of the elasticity of total consumption with respect to net financial wealth obtained from simple s tructural VAR (SVAR) models, including the VAR of Ludvigson, Steindel and Lettau (2002, LSL in chart 4.2). As Table 4.2 and Charts 4.2 show, their estimates suggest that the MPC out of wealth is between 1 and 4 cents per euro for most European countries under review, but with markedly higher values for Germany (around 8 cents per euro on average) and negative values for Portugal. ${ }^{12}$ As Chart 4.2 shows, the relative size of these cross-country estimates remains broadly similar across different specifications of the VARs. ${ }^{13}$ Compared to other studies, the response in Germany seems rather strong. However, the elasticities for equity wealth will be significantly modified when the results are re-scaled for the relative holdings of equity wealth across countries. Estimated MPCs for the United Kingdom, the United States, Canada and Japan are higher than in Europe being in the range of 4 to 8 cents per dollar (or pence per pound, or yen per 100 yen).

Case et al. (2001) use extensive panel data to investigate the link between consumption and increases in housing and equity wealth. They rely on two bodies of data: (1) a panel of annual observations covering 14 countries over the last 25 years and including aggregate consumption, stock market capitalisation, and aggregate housing wealth and (2) an analogous panel of quarterly observations of US states including consumption, stock ownership, and aggregate housing wealth. Their main finding in both data sets is that the housing market seems to be more important than the stock market in influencing consumption. The fact that Case et al. (2001) define their variables in per-capita terms might help to explain why stock market wealth is not significant. Although the stock market had played an important role in explaining aggregate consumption, it may not have been as significant in explaining the behaviour of an average consumer, as most consumers do not hold equities and, hence, stock owners are underrepresented in the sample. Even though equity ownership has become more widespread, the distribution of equity holdings is still fairly skewed (see Table 3.2.3), while housing wealth is much more evenly distributed across households.

The estimated elasticity from housing wealth to consumption is 0.11 to 0.14 in Europe and 0.062 in the United States, when the panel data of the US states are used. By using the information contained in Tables 3.1 and Chart 4.1, these elasticities imply that the MPCs out of housing wealth would be 7.5 to 9.5 cents per euro for Germany, 5 to 7 cents per euro for

12 The high estimates for Germany may be due to the structural breaks in the series associated with unification.

13 The variables included are aggregate consumption, income, inflation, net financial wealth, interest rates, and, in the case of the 6-variable VAR, commodity prices. Restrictions are imposed on the short-run responses of variables. In Chart 4.2 we refer to the SVARs as "LSL", which comes from the names of the authors who originally used the restrictions in these SVARs (Ludvigson, Steindel and Lettau, 2002).
4 ASSET PRICE EFFECTS VIA THE WEALTH CHANNEL: EMPIRICAL EVIDENCE 


\begin{tabular}{|c|c|c|}
\hline & TMT & Non-TMT \\
\hline Canada & 7.3 & 7.2 \\
\hline United States & 1.7 & 5.1 \\
\hline United Kingdom & 2.9 & 3.4 \\
\hline $\begin{array}{l}\text { North America and } \\
\text { United Kingdom average }\end{array}$ & 4.0 & 5.2 \\
\hline France & 4.1 & 1.9 \\
\hline Germany & 2.8 & 0.1 \\
\hline Netherlands & 4.5 & 1.1 \\
\hline Continental Europe average & 3.8 & 1.0 \\
\hline Japan & 6.4 & 13.1 \\
\hline
\end{tabular}

France and Italy and around 4 cents per dollar for the United States.

Edison and Sløk (2001) investigate stock price impacts on consumption with a special focus on the different effect of changes in telecommunications, media and information technology (TMT) and non-TMT stocks. Estimating a reduced-form VAR for seven OECD countries for 1990 s, the empirical analysis suggest that both TMT and non-TMT stocks may have a significant impact on consumption in Canada, the United Kingdom, and Japan. In the United States the effect on consumption of a change in non-TMT market capitalisation was larger than for the TMT sector, while in continental Europe the impact of TMT equities on consumption was clearly dominant.

4.3.2.2 Evidence based on single-country studies This sub-section reviews single-country studies. We start with the US evidence because the bulk of empirical work has been done with US data.

\section{The US evidence}

The role of wealth effects on consumption has been most extensively studied for the United States, and this field of research has grown significantly in recent years. Commonly cited

\begin{tabular}{|c|c|c|c|}
\hline & $m p c_{W-E Q}$ & $m p c_{W-N E Q}$ & $m p c_{w}$ \\
\hline \multicolumn{4}{|l|}{ Ludvigson \& Steindal } \\
\hline \multicolumn{4}{|l|}{ Disposable income: } \\
\hline Mehra & & & \\
\hline \multicolumn{4}{|l|}{ Labour income } \\
\hline - non-durables & 3 & 3 & 3 \\
\hline \multicolumn{4}{|l|}{ Davis \& Palumbo } \\
\hline Labour income & 5.7 & 8.0 & 6.3 \\
\hline $\begin{array}{l}\text { Disposable income } \\
\text { Palumbo et al. } \\
\text { Labour income: }\end{array}$ & - & - & 3.9 \\
\hline - scaled non-durables & 6.0 & 11.3 & 6.9 \\
\hline - total consumption & 5.4 & 10.2 & 6.1 \\
\hline Disposable income: & & & \\
\hline - total consumption & - & - & 4.0 \\
\hline
\end{tabular}

estimates of the MPC out of wealth in the United States are typically in the range of 2 to 5 cents increased spending from a dollar increase in wealth. ${ }^{14}$ Among other estimates using timeseries consumption, income, and equity wealth data, Reifschneider, Tetlow, and Williams (1999) note that in the Board of Governor's FRB-US Model, wealth effects from higher stock prices generate on average about $3 \frac{1}{2}$ cents additional consumer spending in the long run. As shown in Table 4.4, the results reported by Ludvigson and Steindel (1999) and Mehra (2001) are in line with earlier estimates. However, the estimates of Davies and Palumbo (2001) and, especially, Palumbo et al. (2002) are somehow higher.

According to these studies the MPC out of total wealth and its components are markedly higher than conventional estimates if the income variable in the estimated equation is measured in terms of labour income instead of disposable income. In addition, Palumbo et al. (2002) remarked that the conventional practice of deflating income and wealth by a price index for total consumption expenditures, but using a

14 In his February 2000 Monetary Policy Report testimony, Federal Reserve Board of Governors Chairman Alan Greenspan noted that "historical evidence suggests that perhaps three to four cents of every additional dollar of stock market wealth eventually is reflected in increased consumer purchases." 
scaled version of real consumption of nondurables and services, is inconsistent. A more detailed discussion is presented in the Appendix of this work. Correcting this incompatibility, which also improved the cointegration properties of the estimated long-run equation, resulted in markedly higher estimates for the MPC out of equity wealth (6.0), nonequity net worth (11.3) and total wealth (6.9).

However, as discussed in the previous subsection, Lettau and Ludvigson (2002) indicated that if much of the variation in wealth is transitory and uncorrelated with consumer spending, then the MPC out of wealth $m p c_{W}$ is not a good summary statistic for the wealth effects on consumption. They estimated that as much as $88 \%$ of the variance in wealth is transitory. If applied to their $m p c_{W}$ value of 4.6, the implied corrected summary statistic $m p c_{\text {corr }}$, as shown by equation (2.9), would be 1.2 . However, Palumbo et al. (2002) challenged this evidence. They argue that the MPC out of wealth should vary, reflecting variations in the expected rate of return. Recursive estimations over the past thirty years indicate that this has not been the case. Hence the size of the transitory (mean-reverting) component in wealth changes remains controversial.

\section{The European evidence}

Table 4.5 summarises the estimation results of individual country studies as well as providing some information on methodology and data issues. Depending on the estimation approach, long-run coefficients are reported for different wealth components. For Germany, according to the Deutsche Bundsbank's macroeconometric multi-country model (BbkM), the long-run net financial wealth elasticity is 0.14 . The wealth elasticity reported by the Banque de France was half of that, at 0.07 . Sveriges Riksbank reports an elasticity for non-human net wealth of 0.12 (in real terms) in an unpublished study. This estimate is compatible with the Clapham et al. (2002) estimates for Sweden, which are in the range of 0.06 to $0 .{ }^{15}$, and for Finland, in the range of 0.07 to 0.014 . For Spain, Willman and Estrada (2002) estimated a wealth elasticity of
0.26 , which is broadly in line with Balmaseda and Tello (2002), with wealth disaggregated into equity, non-equity financial and housing wealth. However, a more recent estimate of wealth elasticity by Estrada et al. (2004) was much lower at 0.04.17 For the United Kingdom, the Bank of England reports an elasticity of 0.06 (single equation response) and 0.11 (full model response) for net financial wealth. Belgium estimates a markedly lower financial wealth elasticity of 0.02 to 0.04 .

According to an unpublished analysis, the long-run elasticity of equity wealth is 0.02 for Finland, 0.06 for Spain and zero for Sweden, where equity wealth is limited to market values of listed shares for Sweden, Spain and Finland.

Reported MPCs out of equity wealth and nonequity financial wealth were 2 cents per euro and 7 to 9 cents per euro respectively for Germany. Reported (or implied by corresponding elasticity estimates) MPCs out of total physical capital and financial wealth were 3 cents per euro for Portugal (in 1997 ), 2 to 4 cents per euro for Finland, 4 to 5 öre per krona for Sweden and 2 pence per pound for the UK (in 2001). The UK disaggregated estimations for the MPCs out of net financial wealth and housing wealth are 4 pence and 2 pence per pound, respectively (March 2002 figures). Italy reported an MPC out of total wealth in the range of 1.5 to 2.0. Also in the Banca d'Italia Quarterly Model, where the MPC out of total wealth depends on the real interest rate, a value of 1.5 is obtained for a real interest rate of $2 \%$. With these estimates the reported MPC was consistently somewhat higher out of financial wealth (2.7) and somewhat lower out of housing wealth (1.4).

15 Estrada et al. (2004), in defining nominal total wealth, apply the Madrid stock index to the volume of total productive capital, while Willman and Estrada (2000) define this wealth component at repurchasing prices. The former practice results in a markedly wider cyclical variation in the wealth-toconsumption ratio and, hence, in a lower elasticity estimate than latter practice. However, only a proportion of companies are quoted in the stock market and only some of the companies are owned directly by households. Hence, the former practice tends to result in a downwardly biased and the latter practice an upwardly biased elasticity estimate.
4 ASSET PRICE EFFECTS VIA THE WEALTH CHANNEL: EMPIRICAL EVIDENCE 


\subsection{OVERVIEW OF RESULTS}

Some finding based on micro-data evidence support the existence of a direct wealth effect on consumption. For instance, Maki and Palumbo (2001) find that essentially all of the increased spending observed in the aggregate data can be attributed to an increase in the MPC out of income of the richest households. However, there is no consensus regarding the size of the MPC out of wealth and its components. The range of MPC out of wealth estimates across countries and often also across studies within the same country is wider than theory would suggest on the bases of crosscountry differences in wealth composition and

\begin{tabular}{|c|c|c|c|c|c|c|}
\hline & Greece & Finland $^{1)}$ & Belgium & France & Germany ${ }^{7)} \mid$ & Italy \\
\hline Estimation period & $61-97$ & $79-98$ & $81-01$ & $78-01$ & $80-03$ & $80-01$ \\
\hline Data frequency & Q & Q & Q & Q & Q & Q \\
\hline Long-run elasticity of current income & & $0.7-0.94$ & $0.96-0.98$ & & 0.74 & \\
\hline (proxy for human wealth) & & 0.4 & & & & \\
\hline $\begin{array}{l}\text { Long-run elasticity of total non-human net wealth } \\
\text { (incl. housing) }\end{array}$ & & $0.07-0.14$ & & 0.07 & 0.31 & \\
\hline Long-run elasticity of net financial wealth & & & & & 0.14 & \\
\hline Long-run elasticity of financial wealth & & & $0.02-0.04$ & & & \\
\hline Long-run elasticity of equity wealth & & 0.02 & & & 0.01 & \\
\hline Long-run elasticity of non-equity net financial wealth & & 0.08 & & & 0.10 & \\
\hline \multicolumn{7}{|l|}{ Long-run elasticity of non-equity financial wealth } \\
\hline Long-run elasticity of housing wealth & & 0.05 & & & & \\
\hline MPC out of total net wealth & & $2.1-4.1$ & & 1.6 & 4.4 & $1.5-2$ \\
\hline MPC out of financial wealth & & & & & & 2.7 \\
\hline \multicolumn{7}{|l|}{ MPC out of net financial wealth } \\
\hline MPC out of non-equity net financial wealth & & & & & $7-9$ & \\
\hline MPC out of equity wealth & & & & & 2 & \\
\hline MPC out of housing wealth/physical capital & 6.8 & & & & & 1.4 \\
\hline \multirow[t]{2}{*}{ Dependent (endogenous) variables ${ }^{6}$} & $\mathrm{C}$ & $\mathrm{C}$ & $\mathrm{C}$ & & VECM & $\mathrm{C}$ \\
\hline & Portugal & $\begin{array}{l}\text { Nether- } \\
\text { lands }\end{array}$ & Spain & Sweden & UK & $\begin{array}{r}\text { UK (full } \\
\text { model) }\end{array}$ \\
\hline Estimation period & $58-97$ & $?$ & $80-01$ & $79-98$ & $75-01$ & 75-01 \\
\hline Data frequency & A & Q & Q & Q & Q & Q \\
\hline Long-run elasticity of current income & 0.94 & & $0.68^{2)}$ & $0.4-0.6^{1)}$ & & \\
\hline (proxy for human wealth) & & & $0.74^{4)}$ & $0.16^{1)}$ & & \\
\hline $\begin{array}{l}\text { Long-run elasticity of total non-human net wealth } \\
\text { (incl. housing) }\end{array}$ & 0.03 & & $\begin{array}{l}0.04^{3)} \\
0.26^{4)}\end{array}$ & $\begin{array}{r}0.06-0.17^{1)} \\
0.12^{5}\end{array}$ & & \\
\hline Long-run elasticity of net financial wealth & & & & & 0.06 & 0.11 \\
\hline Long-run elasticity of financial wealth & & & & $0.14^{1)}$ & & \\
\hline Long-run elasticity of equity wealth & & & $0.06^{2)}$ & & & \\
\hline \multicolumn{7}{|l|}{ Long-run elasticity of non-equity net financial wealth } \\
\hline Long-run elasticity of non-equity financial wealth & & & $0.11^{2)}$ & & & \\
\hline Long-run elasticity of housing wealth & & & $0.15^{2)}$ & $0.05^{1)}$ & & \\
\hline MPC out of total net wealth & 3 & 2 & $7.7^{4)}$ & $4-5^{5)}$ & & 2 \\
\hline \multicolumn{7}{|l|}{ MPC out of financial wealth } \\
\hline MPC out of net financial wealth & & & & & & 3.7 \\
\hline \multicolumn{7}{|l|}{ MPC out of non-equity net financial wealth } \\
\hline \multicolumn{7}{|l|}{ MPC out of equity wealth } \\
\hline MPC out of housing wealth/physical capital & & & & & & 1.9 \\
\hline Dependent (endogenous) variables ${ }^{6}$ & $\mathrm{C}$ & & $\mathrm{C}^{4)}$ & $\mathrm{C}$ & $\mathrm{C}$ & VAR \\
\hline \multicolumn{7}{|l|}{ 1) Clapham, Hyytinen and Takala (2002). } \\
\hline \multicolumn{7}{|l|}{ 2) Balmaseda and Tello (2002). } \\
\hline \multicolumn{7}{|l|}{ 3) Estrada et al (2004). } \\
\hline \multicolumn{7}{|l|}{ 4) Willman and Estrada (2002). } \\
\hline \multicolumn{7}{|l|}{ 5) Sveriges Riksbank. } \\
\hline \multicolumn{7}{|l|}{ 6) $\mathrm{C}=$ private consumption. $\mathrm{VAR} / \mathrm{VECM}=$} \\
\hline 7) Hamburg, Hoffmann and Keller (2005). & & & & & & \\
\hline
\end{tabular}


demographics. Estimates for the United States are an exception in that both micro and macro studies consistently confirm the existence of a wealth effect on consumption. The range of MPC out of wealth estimates using US data is also theoretically feasible. Further, some US studies find somewhat lower MPC out of equity wealth than out of non-equity wealth. In Europe, the German and Italian (panel data) evidence supports this view.

Typically, MPC out of wealth estimates in international comparisons have been smaller for continental EU countries than for the English-speaking countries. Both crosscountry and single-country studies broadly support this view. However, this is not uncontroversial, especially since estimates for European countries are often smaller than would seem admissible on theoretical grounds. Also unlike in most other studies, the MPC out of wealth estimates presented by Labhard et al. (2005) stand out as being quite high for Germany, exceeding their estimates for the United States. Likewise a reported estimate for the MPC out of non-equity net financial wealth was in line with the corresponding US estimates. In addition, the panel data studies of Ludwig and Sløk (2002) and Case et al. (2001), which try to separate equity and housing wealth effects on consumption, found quite high MPC out of wealth estimates for housing wealth in European countries. Furthermore, Edison and Sløk (2001) found that consumption in European countries was more sensitive to variation in the market value of "New Economy" stocks than was consumption in the United States.

Data problems may be a potentially important source of wide cross-country variation in estimated MPCs. Data problems are apparent in many of the studies referred to in this report. In international comparisons in particular, stock market capitalisation, stock prices and housing prices have often been used as proxies for the level of their respective wealth components. There are also differences across countries in the measurement of wealth. Although agreed guidelines are generally followed, the specific methodology applied in each country depends on data availability. As the more detailed presentation in Appendix 1 shows, the treatment of sole proprietorships, for instance, differs in European countries and in the United States. Methods of estimating the value of unlisted companies also vary across countries.

\subsection{HOW SIGNIFICANT ARE CROSS-COUNTRY DIFFERENCES IN ESTIMATED MPC OUT OF WEALTH?}

Our analysis suggests that cross-country comparisons based on empirical estimates of the MPC out of wealth may be unreliable. We find it implausible that demographic and structural differences between countries could explain cross-country differences in MPC out of wealth as large as those suggested in the empirical literature. In contrast, we find good reasons to believe that data mismeasurement and structural shocks that vary across time and across countries may lead to estimates of the MPC out of wealth that differ widely across countries. Therefore, we might also expect empirical estimates of the MPC out of wealth to be imprecise. Thus despite the apparently large differences in point estimates of MPC out of wealth across countries, we may be unable to reject the hypothesis that such differences are not significant. Labhard et al. (2005) give recent evidence on this issue. They apply a dynamic panel approach recently suggested by Pesaran et al. (1999). Subject to a specification in which the parameters can be interpreted as MPC out of wealth, their pooled mean group estimator (PMGE) can test cross-country restrictions on the long-run MPC out of wealth, while taking into account possible crosscountry differences in the adjustment to this common long-run MPC out of wealth. Therefore, a PMGE-based direct estimate of the MPC out of wealth is likely to provide a theory-consistent guide to wealth effects on consumption, and a better guide than estimates obtained from either traditional panel methods
4 ASSET PRICE EFFECTS VIA THE WEALTH CHANNEL: EMPIRICAL EVIDENCE 
or single equation techniques. ${ }^{16}$ In this case, traditional panel methods, including the fixed and random effect estimators, are overly restrictive, since they force all coefficients except the intercepts to be identical across countries. The PMGE-specification is written as follows:

$\Delta\left(\frac{\mathrm{C}_{\mathrm{t}}}{\mathrm{Y}_{\mathrm{t}}}\right)_{\mathrm{i}}=\gamma_{0, \mathrm{i}}+\gamma_{1, i} \Delta\left(\frac{\mathrm{C}_{\mathrm{t}-1}}{\mathrm{Y}_{\mathrm{t}-1}}\right)+\gamma_{2, \mathrm{i}} \Delta\left(\frac{\mathrm{W}_{\mathrm{t}}}{\mathrm{Y}_{\mathrm{t}}}\right)+\alpha_{\mathrm{i}}\left[\frac{\mathrm{C}_{\mathrm{t}-1}}{\mathrm{Y}_{\mathrm{t}-1}}-\beta \frac{\mathrm{W}_{\mathrm{t}-1}}{\mathrm{Y}_{\mathrm{t}-1}}\right]$

All parameters except the MPC out of wealth $(\beta)$ are country-specific. Therefore, the PMGE provides a means to test the hypothesis that the MPC out of wealth is identical across countries. Labhard et al. (2005) estimated the above equation for the panel of 11 countries. Their estimate for $\beta$ is 6.8 , which is somewhat higher than the average of the individual country estimates (4.8). In addition, specification test supported the hypothesis that the MPC out of wealth is equal for all countries in the panel, although some of the singlecountry estimates yielded results which were not economically sensible. ${ }^{17}$

\subsection{CONCLUSIONS}

A number of studies have estimated significant wealth effects across a very broad range of EU and non-EU economies.

Wealth-consumption ratios differ markedly across countries, and, in principle, may provide an indication of the relative strength of wealth effects in aggregate and across a range of assets. However, an important contribution of this study is to suggest that methodological differences in compiling household balance sheet data still remain across countries and they may have exaggerated the cross-country differences in wealth-consumption ratios. The effect of equity price changes on household wealth in Germany, for example, may be relatively understated, while those in the United States may be overstated. Any such measurement discrepancies will inevitably be built into model-based estimates of wealth effects since models re-value equities according to published data.

Calibrated theory-based models give a good benchmark for an expected MPC out of wealth. For instance, the cross-country estimates of MULTIMOD are in the range of 5.4 to 8.2 cents per euro (cents per dollar). Although the available evidence is rather sparse, MPC out of wealth estimates based on the direct estimation of the theory-based equations are well in line with calibrated estimates, being in the range of 3 to 10 cents per euro (cents per dollar), if the some highest outlying estimates are excluded. On the bases of these estimation results, no clear evidence can be found for MPC out of wealth being lower in the continental Europe than in the English-speaking countries.

Individual country studies find elasticities to total non-human wealth in the range 0.03 to 0.17 for European countries, while the MPC is in the range of 1.5 to 7.5 . Studies which provide pooled estimates of MPC tend to show higher values for the United States and the United Kingdom than for other European countries. On the other hand, estimates from VAR models show smaller differences between European countries, especially Germany, and the United States. Though many existing empirical studies estimated plausible MPCs out of financial wealth, the differences across countries and across studies for the same country are rather large. They can only be explained by combination of factors (different time horizons, demography, distribution of wealth, time-varying rates of return) including inconsistencies in the data that are used. Interestingly, the panel data estimation technique, developed by Pesaran (1999), which is less sensitive to cross-country incompatibilities in data construction,

16 Moreover, due to its flexibility, the PMGE is particularly suitable for the "large N, large T" case, i.e. when the crosssectional and time-series dimensions are both large and similar in magnitude, as is usually the case in cross-country studies.

17 Pesaran et al. (1999) have argued that this is one of the situations in which the PMGE is particularly useful. 
provided the MPC out of wealth estimate of 6.8 cents per euro, which is comparable with a typical estimate for the United States. More importantly, cross-country differences in the MPC out of wealth estimates were not statistically significant.

Finally, there is some empirical support for the hypothesis that housing wealth may have stronger impact on consumption than equity wealth in some EU countries, although the evidence is scarce and inconclusive. But relatively little cross-country research has been done to try to study the simultaneous relationship between asset price and consumption changes, or how the consumption response might differ according to the cause of the shock to equity prices.

5

\section{ASSET PRICES AND INVESTMENT}

In addition the effects described above, asset prices may also have an effect on economic activity through its effect on investment. In particular, equity prices may affect corporate sector investment and house prices may affect residential investment. This section reviews the available evidence of asset price effects on both of these investment components.

\section{I STOCK PRICES AND CORPORATE INVESTMENT}

Share prices may also affect economic activity by changing the cost of equity capital to finance corporate investment. Changes in share prices may also alter the financial structure of the company, affecting the cost and the availability of external funds. Finally, changes in share prices that reflect information about the future prospects in the economy, may affect expectations and therefore investment plans.

More formally, the mechanisms described above are usually classified in the following three channels:
1. Tobin's Q or cost-of-capital channel

2. Balance sheet channel

3. Confidence channel

In general, empirical evidence linking share prices and investment is limited. When the investment equation accounts for alternative explanatory variables, share prices still play a role in explaining investment, but the impact of cash flow and sales suggest that the balance sheet channel and the confidence channel may be more important than the cost of capital channel.

There are several possible reasons for this rather weak link between investment and share prices. First, when share prices are low companies may substitute debt financing for equity financing and when share prices are high companies may use funds obtained by equity financing to improve their financial structure or for mergers and acquisitions instead of investing. Second, response of investment may depend on the source of a given change in stock prices. Temporary changes in share prices may not have the same impact on investment as changes perceived as permanent. Empirically, however, it is difficult to establish how companies perceive movements in the stock market. In other words, it is difficult to determine whether share prices reflect the fundamental value of the company or carry a speculative component.

Moreover, all these factors will affect investment simultaneously through the three channels listed above. While speculative movements in share prices should not affect investment through the cost-of-capital channel, they may have an impact through the confidence channel. Similarly, while an increase in share prices may not stimulate investment through the reduction in the cost of capital, companies may use equity issues to improve their financial position, affecting investment through the balance sheet channel.

In practice it is very difficult to disentangle the effect of each of these channels on investment, 
so in the following we concentrate on Tobin's Q channel. A separate review on the balance sheet and confidence channels given in Appendix 3 suggests that the balance sheet effect through cash flow may be very important, in particular for small (and young) companies. However, given that these companies are unlikely to be listed on the stock exchange, it is difficult to identify a direct effect of stock prices on investment through the balance sheet. Changes in stock prices may also be transmitted to investment through the banklending channel. When stock price movements lead to a deterioration in bank balance sheets, this reduces their willingness/capability to lend. Finally, although there seems to be a close relationship between stock prices and confidence in the euro area, empirical estimation of a separate confidence channel on investment is rather difficult.

\subsection{TOBIN'S Q OR COST-OF-CAPITAL CHANNEL}

In theory a change in share prices implies a change in the cost of raising equity capital to finance corporate investment. This has been formalised theoretically in Q theory (Tobin, 1969) which describes how movements in stock prices can affect investment. For example, a company may perceive the cost of equity capital to be rather high in periods when the company's stock price is low compared to earnings per share. As a result, companies may reduce investment in projects previously perceived as profitable.

According to Tobin's Q theory, the company should invest as long as the market value of an investment exceeds the replacement cost of that investment. Marginal Q is defined as the change in the market value of a company divided by the change in its capital stock (investment) that caused the change in market value. If marginal $Q$ is larger than one, the market price of companies is high relative to the replacement cost of capital, and new plant and equipment capital is cheap relative to the market value of the company. The company can then issue stocks at a high price relative to the cost of the facilities and equipment they are buying. In this case, investment spending will rise because companies can now buy more new investment goods with only a small issue of stock.

Although in practice marginal $Q$ is not observable, average Q can be expressed as the market value of the company divided by the replacement cost of capital. Hayashi (1982a) proves that under certain conditions average $\mathrm{Q}$ is equal to marginal $Q$. Therefore, most empirical studies use average $Q$ and set the market value of the company at the share price. An increase in share prices makes it cheaper for companies to finance their investment because each share issued yields more funds. Thus, an increase in stock prices lowers the cost of capital, stimulating investment. In this theory, no other variables are needed to explain investment because all expectations including future revenue are captured in share prices.

Thus, the investment equation can be written as: ${ }^{18}$

$$
\left(\frac{I_{t}}{K_{t}}\right)=a+\frac{1}{b}\left(\frac{V_{t}}{(1-\delta) p_{t}^{K} K_{t-1}}-1\right)=a+\frac{1}{b} Q_{t}
$$

where $I_{t} / K_{t}$ is the investment ratio; $V_{t}$ is the fundamental value of the company, given by the discounted present value of the cash-flow stream expected from the existing capital stock; the expression $(1-\delta) p_{t}^{K} K_{t-1}$ is the replacement cost in period t of the capital stock that the company inherits from the previous period. As mentioned before, $V_{t}$ is measured by the company's share price.

The theory assumes that stock markets are strongly efficient, in the sense that the fundamental value of the company can be measured by its stock market valuation. Thus, stock prices should reflect the value of the company given by the discounted present value of the cash flow and this should contain all available information about the company. Given this assumption, the only information

18 See e.g. Bond and Cummins (2001). 
necessary to estimate a company's investment demand is given by Q. Since information about the financial structure or expectations about future revenue should be known, these should be reflected in share prices. ${ }^{19}$

However, empirical studies using multivariate regressions have almost unanimously failed to find evidence of an effect of share price on investment expenditure. For example, Tease (1993) concludes: "When other determinants of investment are controlled for, share prices do not seem to explain much of the variation in investment in any of the G7 countries."20 Blanchard et al. (1993) and Morck et al. (1990) also examine the effect of share prices on investment and report similar results. While (non-residential) investment expenditure remains hard to explain, the relative importance of other key factors is confirmed by various studies: Chirinko (1993) concludes: "...output (or sales) is clearly the dominant determinant of investment spending with user cost having a modest effect." Moreover, "the usefulness of the Q-theory is called into question by its generally disappointing empirical performance." 21

Some authors attribute these disappointing results to the use of share prices as indicators of the fundamental value of the company when stock markets are not efficient. There are several reasons why the valuation of the company by managers and the market may diverge:

1. the market may have less information

2. even if the information is the same, the market may not value assets at their fundamental value, and the share price may include a rational speculative bubble

3. the market may be subject to fads that cause market valuation to deviate from fundamentals for long periods.

In theory, companies will react only to permanent changes in share prices and will tend to ignore movements in share prices that are considered fads or bubbles.

Thus, some authors have attempted to distinguish between the components of the share price that reflect the fundamental value of the company and the residual speculative component. Thus the fundamental value of the company may be expressed as the market value less the speculative or "valuation" component:

$V_{t}^{F}=V_{t}-V_{t}^{S}$

In the literature, fundamentals have been proxied by sales, cash flows, dividends, and analysts' earnings forecasts, among other variables.

Blanchard et al. (1990) made one of the first attempts to perform this decomposition. They investigated whether managers ignore share prices when they deviate from fundamentals, but could not reach a definite conclusion. While there is no clear evidence of a bubble in 1929, the evidence in 1987 suggests managers ignored market developments.

Bond and Cummins (2001) constructed a measure of average Q for a group of US companies using analysts' forecasts instead of share prices. They conclude that stock market valuations deviate significantly from fundamental values, rendering share prices useless to explain investment.

A similar approach was followed by Anderson and Subbaraman (1996) for Australia. They estimate the fundamental and speculative component of share prices and find that the fundamental component has a stronger relationship with investment than real share

19 This means that the information provided by the financial structure of the company and expectations about future revenue, which are of central importance for the balance sheet and confidence channels, should also be captured by average Q.

20 Tease (1993), p. 58.

21 Chirinko (1993). 
prices, while the speculative component does not seem to have any significant effect on business investment. Evidence for Japan is also mixed. Goyal and Yamada (2004) find that the speculative component affects investment during asset prices booms, while fundamentals matter more after asset price collapses. Chirinko and Schaller (2001) use the Q model to test whether there was a stock market bubble in Japan in the late 1980's. Their results confirm the existence of the bubble and also that developments in stock prices during this period affected business investment.

Some authors have also tried to explain the lack of supporting evidence for the cost of capital channel by arguing that companies with access to other sources of funds will not react to stock prices in the same way as equity-dependent companies (Baker et al, 2002). However, Goyal and Yamada (2004) found that bank-dependent companies in Japan show a stronger reaction to share prices.

More promising results have been found when other variables are included in the investment equation. Even when there is no separation between speculative and fundamental components of share prices, the significance of additional variables in the investment equation suggests that share prices do not reflect all companies' investment opportunities as stated in the original theory. In other words, this provides evidence that stock markets are not highly efficient, or that there are measurement problems in Q. Some studies using this methodology are described below.

Ashworth and Davis (2001) estimate investment equations for the G7 countries including average $\mathrm{Q}$ as well as other financial variables. Average $Q$ is significant only for Japan and France.

Audretsch and Elston (2002) estimate an investment equation for German companies in which both $\mathrm{Q}$ and some financial constraints are included. Their results show that $Q$ is significant for two groups of companies: the smallest and the second-largest companies in their sample. This partly confirms the findings of Baker et al (2002) since the smallest companies may have less access to external finance from banks. However, it is puzzling that the largest companies do not react to share prices while the second-largest do.

Alonso and Bentolila (1992) find that Tobin's $\mathrm{Q}$ is only partially significant for explaining fixed capital investment by Spanish industrial companies. The elasticity of investment to changes in the stock market is rather low, a result compatible with Spain's poorly developed financial markets at that time. Sensitivity analyses suggest that estimated coefficients are not stable, although the qualitative conclusions are maintained. As is often found in other studies, the significance of financial variables, such as internal finance or cash flow rejects the simplest version of the $\mathrm{Q}$ model - namely that Q is a sufficient statistic for investment.

Van Ees and Garretsen (1994) consider Tobin's $Q$ in studying the effects of liquidity on investment in a group of Dutch companies. They also include financial variables such as cash flow, the stock of liquid assets, and the working capital. Their evidence corroborates previous findings that once sales and financial variables are included in the equation, the effect of Tobin's Q on investment is very small or insignificant. Moreover, these results do not change when the sample is split according to company size or dividend pay-out. While the effect of financial variables depends on whether companies have close ties with banks, the small effect of Tobin's Q on investment is not affected by the existence of bank lending relationships.

Assarsson et al (2004) use a neoclassical investment model extended with installation costs for capital, agency costs for investment financing, and the possibility of the company being output constrained as a framework for an empirical analysis of investment behaviour in the Swedish manufacturing industry. Using a 
multivariate error-correction model on data covering the time period 1951 to 1995 their results show that Tobin's average $\mathrm{Q}$ is not the sole determinant of investment, neither in the short nor in the long run, and other variables like real output and capital gearing also affect investment activity.

\subsection{HOUSE PRICES AND HOUSING INVESTMENT}

Exactly as in the case of corporate investment, there should also be a relationship between Tobin's Q and residential investment. According to Tobin's Q theory, the supply of houses will increase when it becomes profitable for a construction company to build more houses. This will happen when the price at which the house can be sold is higher than its constructions costs. This is when Tobin's Q, which is the ratio between house prices and construction costs, is larger than 1 . Thus, rising house prices will be accompanied by an increase in the supply of houses, i.e. housing investment. In the long run, however, the increased supply of houses forces real house prices to fall and Tobin's Q to converge back to unity.

As in the case of corporate investment, Tobin's Q for residential investment is not observable and its calculation poses a number of problems. The price of houses should take into account improvements in quality, which are in general very difficult to measure. In empirical studies

construction cost also poses a problem, so it is proxied by the deflator for private residential investment. This measure, however, does not take into account the cost of land, which may account between 20 and 40 percent of total building costs and which has increased even faster than house prices in some countries. ${ }^{22}$

Due to the lack of data there are few countries for which studies have attempted to relate housing or residential investment to a measure of Tobin's Q. Examples of two European macromodels, which apply the Tobin's Q approach are the models of Suomen Pankki,
BOF5 (1999), and Danmarks Nationalbank, MONA (2003). In both models, but especially in BOF5, housing investments reactions to real house prices play a central role in balancing housing demand and supply. BOF5 simulations indicate that the elasticity of housing investment with respect to real housing prices is about 0.9 . These results are close to those estimated by Kenny (2003) for Ireland, who found long-run elasticity of housing investment with respect to real house prices of around 1.0 .

Based on the data of some selected OECD countries in the period 1980-1999, Girouard and Blöndal (2001) find strong correlation (above 0.8) between housing investment and real house prices in Belgium, Denmark, the Netherlands and Spain. Only very weak correlation is found for the larger countries (United States, Japan, France) and for Norway. Evidence for Germany is tainted by the lack of good data for the new Länder. However, this evidence does not confirm whether there is a long-term relationship between Tobin's Q and private residential investment.

Barot and Yang (2002) analyse house prices and housing investment in Sweden and the UK. Their results show that Tobin's Q “Grangercauses" housing investment in both countries. Further, based on the error correction approach for the sample period 1970-1998, their results indicate that in the short run Tobin's Q is significant only in the United Kingdom, but in the long run is significant in both countries. However, as discussed by Muellbauer (2004), it is a generally accepted view is that the United Kingdom is a country, where the price elasticity of the supply of new houses is small, being close to zero and probably lower than 0.5 .

We may conclude that the available evidence indicates that in many countries housing investment depend positively on the real price of housing. However, it is also likely that the

$22 \operatorname{OECD}(2001)$.
ASSET PRICES

AND

INVESTMENT 
strength of these supply responses vary markedly across countries.

\section{CONCLUSIONS}

This report reviews the available theoretical and empirical evidence regarding asset price and wealth effects in Europe and some other major economies. For the most part, the work is of a stock-taking nature, although some new and unpublished material is also included in the analysis. The main focus of this report is on consumption effects via the wealth channel, reflecting the bulk of literature on the effects of asset prices. However, asset price effects on investment via the Tobin's-Q channel are also reviewed. In addition, Appendix 3 reviews possible asset price effects on private spending via balance sheet and confidence channels. The available evidence supports the view that the wealth channel is the most important of various channels. There is little empirical evidence indicating that the Tobin's-Q, balance-sheet and confidence channels play any major independent role in the transmission of asset price effects to economic activity. The key findings in more detail are as follows:

- A baseline theoretical analysis revealed that the size of the wealth effect on consumption should depend on the following elements. First, the wealth effect depends inversely on the length of planning horizons (expected remaining lifetime) or the strength of the bequest motive. Second, the wealth effect depends positively on the expected risk-adjusted rate of return on wealth, which in turn depends on the expected rate of return on wealth and the subjective discount rate. Higher risk aversion will move the risk-adjusted rate of return closer to the expected rate of return on wealth. Third, if expected returns on assets vary over time, then the response of consumption to changes in wealth may depend on how permanent these changes are expected to be. For example, an increase in stock prices that is expected to be followed by a period of poor returns may have little effect because a decline in the MPC may partially offset the higher level of wealth. Finally, labour income uncertainty implies that consumers in the upper tail of the income distribution may have markedly lower MPC out of wealth than those in the lower tail of the income distribution.

- Computed examples based on the intertemporal budget constraint suggest that reasonable estimates of the MPC out of wealth might be in the range of 3 to 10 cents for each one euro permanent increase in wealth. A natural lower bound for the MPC out of wealth is the equilibrium risk-free interest rate (or the subjective discount rate), but values below that are feasible, if combined with low (i.e. below one) relative risk aversion.

- Based on national data sources, the ratio of gross financial wealth to consumption expenditure varies markedly across countries. However, these differences also reflect differences in statistical and accounting practices, which weaken the international comparability of results. Moreover, stock market capitalisation data typically used in international comparisons are subject to even more severe statistical problems.

- Comparing wealth composition changes through time and across countries, the 1990s saw a striking increase in the share of equity holding by households and, in general, a reallocation of household financial wealth towards more risky assets in most countries. However, there are marked cross-country differences in equity ownership. In the United Kingdom 23\% of the population own shares (in 2000), in the United States this proportion is 19\% (in 1998), in France it is $13 \%$ and in Germany and Italy it is $10 \%$. There are also striking cross-country differences in the ratio of directly held equity wealth to consumption. In 2000 this ratio was around $200 \%$ in the 
United States, 150\% in France, 100-130\% in the Netherlands, Belgium, Italy, Spain and Sweden, $90 \%$ in the United Kingdom, $50 \%$ in Germany and $40 \%$ in Austria. However, in all countries the majority of equities are owned by households in the highest income brackets. Moreover, equity ownership is more common among older age groups, although more so in the United States than in continental Europe.

- International comparisons generally reveal a statistically significant link between wealth and consumption spending. However, the implied MPC out of wealth estimates for EU countries are typically smaller than those reported for the United States, although this is not an uncontroversial result. In particular, panel data estimation yields a MPC out of wealth estimate of 6.8 cents per euro, which is comparable with a typical estimate for the United States. More importantly, crosscountry differences in MPC out of wealth estimates were not statistically significant.

- Panel data studies report higher MPC out of housing wealth in European countries than in the United States, while the situation is reversed for the MPC out of equity wealth.

- Regarding country-specific studies the available econometric evidence on the link between equity wealth and consumption is sparse in Europe. Documented, but quite tentative, elasticities with respect to equity wealth (with implied MPC out of wealth in brackets, where available) are 0.01 for Germany ( 2 cents per euro), 0.02 for Finland ( 1 cent per euro) and around zero for Sweden. On this basis, a permanent $50 \%$ drop in stock prices would imply a downward shift in the level of consumption expenditure of $0.5 \%$ in Germany and $1 \%$ in Finland.

- The link between housing wealth and consumption also seems to be quite country-specific. For some EU countries there appears to be little evidence of an effect on consumption (e.g. Austria, France, Germany and Italy). This may reflect cross-country liquidity differences in housing wealth, but also the fact that Austria, Germany and Italy are countries where house prices have been most stable, which may have made it difficult to identify the impact of housing wealth on consumption. In countries where house prices have been more volatile, a statistically significant positive effect of housing wealth on consumption has typically been found (Finland, Greece, the Netherlands, Spain and the United Kingdom). There is some evidence that in these countries the effects of housing wealth (and house prices) on consumption may be stronger than most reported effects from equity wealth and from financial wealth more generally.

- The United States provides an important benchmark because it has high-quality data sources and has been the subject of most existing econometric studies. US evidence provides robust support for the importance of the wealth channel. In particular, the preferred estimates of the long-run MPC out of wealth were in the range of 6 to 7 cents per dollar. The MPC appears to be somewhat higher for non-equity wealth (about 10 cents), and somewhat lower for equity wealth (about 5 cents). Timevariation in expected returns would imply variation in the MPC out of wealth. However, on the basis of the available evidence it appears that the US wealth effect on consumption has been relatively stable over time.

- Regarding the equity price effects on investment via the Tobin's-Q channel, a general conclusion seems to be that equity prices have no additional explanatory power once other determinants of investment, such as sales or cash flow, are included. Nonetheless, a link from house prices to residential investment has been 
identified in many countries. However, the available empirical evidence is quite sparse and it may be that the impact of house prices on residential investment is quite countryspecific, reflecting, for example, crosscountry differences in the transmission of house prices to construction costs (land prices) and /or the availability of mortgage loans.

- Most studies find that the balance sheet effect, operating through cash flow, seems to be a very important determinant of investment, in particular for small (and young) companies. Given that these companies are very unlikely to be listed on the stock exchange, it is difficult to identify a direct effect of stock prices on investment through the balance sheet. However, changes in stock prices may be transmitted to investment through the bank-lending channel. This may happen when bank balance sheets deteriorate as a result of stock price movements, affecting their willingness or capacity to lend. Finally, although there seems to be a close relationship between stock prices and confidence in the euro area, the separation and empirical estimation of the effects via a confidence channel on investment is rather difficult. 


\section{APPENDIX I}

\section{COMPARABILITY OF EQUITY WEALTH DATA ACROSS COUNTRIES}

While much progress has been made in harmonising methodologies to calculate financial accounts - at the present time all EU countries apply criteria laid down in the European System of Accounts (ESA 95) wealth data for international comparison purposes are still fairly heterogeneous in terms of the compilation criteria. ${ }^{23}$ Differences arise from the concepts themselves, that are not exactly the same across countries, from the ways they are measured and from the fact that the information necessary for applying general guidelines is not available.

There are many differences in the practical implementation of the recommendations of ESA 95 in each country, which affect the published figures. However, the differences in the criteria used to obtain the value of household equity holdings have a greater influence on wealth figures. The main differences are the following:

The treatment of sole proprietorships and partnerships in European countries and the United States is different. In the US financial accounts they are considered non-financial corporations, while in the European countries they are included in the household sector. As a consequence, the whole net worth of sole proprietorships is regarded as household financial assets in the US methodology, while in the other countries, part of this amount (professional buildings, plant and machinery) is regarded as non-financial assets. Therefore, it can be said that, in the United States, the ratio of "shares and other equities" to total assets is overestimated relative to European countries and the total amount of financial assets is also likely to be larger than that which really pertains to households.

The valuation of equities follows the principles of ESA 95, which means that marketable financial instruments are valued according to their market value. This poses a big problem in the case of unlisted shares, which are not traded on organised markets. The general principle of ESA 95 is to estimate the value of unlisted shares with reference to the value of listed shares and to also take into account the sector and the differences between them due to their different liquidity and reserves accumulated. However, the specific estimation method applied by each country very much depends on the basic statistics available. Table A.1 summarises these methods in a very synthetic way for a few countries.

Valuation changes due to exchange rate movements pose an additional problem for estimating the value of shares and participation in foreign companies. Although most of them are held by domestic firms and not directly by households, the estimate of their value also affects the estimated value of domestic companies, which is part of household equity holdings. There is no unified criterion regarding the specific exchange rate to be applied so each country applies what it considers to be appropriate. However, the application of different exchange rate indices is not neutral and may give rise to very significant differences in the value of equity holdings in financial accounts. ${ }^{24}$

According to Table A.1, France and Spain are countries that apply market price criteria (more

23 Comments in this appendix are based on Babeau and Sbano (2002).

24 For example, in Spain there were important revisions of the estimated market value of shares when the index used as a reference to estimate value changes due to exchange rate movements was changed from an effective exchange rate to several individual currency indices. 


\section{Table A.I Data issues in measuring wealth}

Section i: Various practices in the valuation method of unlisted companies

Italy The ESA 95 general principle (capitalisation/own funds ratio of quoted companies of a similar size and activity) is applied for large non-listed companies. For non-listed small to medium-sized companies the valuation applied is according to their book-value.

Spain Unlisted shares issued by banks are valued by applying the ESA 95 general principle. The value of unquoted non-financial companies is estimated as the discounted value of the flow of expected ordinary profits. In practice, the discount rate used is inferred from the valuation of quoted corporations.

France The ratio between the market value of listed companies and their own funds is multiplied by the own funds of unlisted companies. This procedure is currently under revision.

United Kingdom ESA 95 is applied, but work is still being done on estimates.

Netherlands Unlisted shares are evaluated at own resources.

Germany Unlisted shares (public limited companies) are valued using the market capitalisation of listed companies, with considerable discounts reflecting the lower ratio of own funds. Unlisted private limited companies are valued according to their book-value and applying a $30 \%$ increase, in order to take into account reserves.

Section ii: Other examples of measurement issues

Belgium Large stocks of government debt may have a relatively large impact on the valuation of household wealth after adjusting for expected future tax payments.

Germany Data availability of mutual fund equity holdings, insurance company accounting practices.

United States Different sector definition in US flow of funds accounts: 1. narrow definition: household sector does not include self-employed; ${ }^{1)}$ 2. broad definition: household sector includes self-employed and non-corporate firms.

1) In contrast to this sector definition, the German household sector includes households, non-profit organisations and the selfemployed.

closely related to stock markets) to a larger extent. When analysing equity to consumption ratios (Table A.2), France and Spain have experienced a relatively large increase in this ratio in the period 1995-2000, although increasing equity to consumption ratios are a common feature across countries. Therefore, the method applied to estimate the value of equities across countries appears to have a significant influence on the changes of the wealth to consumption ratio over time, though it is difficult to disentangle this effect from other effects on the data, such as privatisation.

\begin{tabular}{llll}
\hline Table A.2 Equity to consumption ratios ${ }^{1)}$ \\
& & & \\
& & & \\
& 1995 & 2000 & Change \\
& & & \\
Italy & & 1.07 & \\
Spain & 0.46 & 1.08 & 0.62 \\
France & 0.64 & 1.54 & 0.91 \\
United Kingdom & 0.60 & 0.90 & 0.29 \\
Netherlands & 0.96 & 1.29 & 0.33 \\
Germany & 0.29 & 0.48 & 0.19 \\
\hline
\end{tabular}

1) Equity is defined here as shares and other equity directly held by the household sector. 
Table A.3 Financial assets held by household sector, measured as percentage of consumption (unless otherwise indicated)

\begin{tabular}{|c|c|c|c|c|c|c|c|c|c|c|c|c|c|c|c|}
\hline \multirow[b]{2}{*}{ National sources } & AT & $\mathrm{BE}$ & FI & FR & DE & IT & NL & PT & SP & SE & UK & US & JP & $\mathrm{AU}$ & $\mathrm{CA}$ \\
\hline & 2000 & 2001 & 2000 & 2000 & 2000 & 2000 & 2000 & 2000 & 2000 & 2000 & 2000 & 2000 & 2000 & 2000 & 2000 \\
\hline Gross financial Wealth & 236 & 539 & 302 & 414 & 304 & 386 & 596 & 312 & 320 & 311 & 502 & 525 & 493 & & \\
\hline Directly held equities & 40 & 121 & 189 & 154 & 48 & 107 & 129 & 73 & 108 & 97 & 90 & 196 & 42 & & \\
\hline Of which & & & & & & & & & & & & & & & \\
\hline quoted & & 44 & & & 37 & & & & & & 52 & 126 & 39 & & \\
\hline unquoted & & 77 & & & 11 & & & & & & 38 & 70 & 3 & & \\
\hline Mutual funds & 9 & 80 & 7 & 36 & 34 & 65 & & 26 & 40 & 40 & 26 & 49 & 0 & & \\
\hline Pensions and life & & & & & & & & & & & & & & & \\
\hline Insurance & & 72 & & 90 & 84 & 47 & 321 & 43 & 41 & & 265 & 150 & 139 & & \\
\hline Cash and Deposits & & 140 & & 110 & 104 & 93 & 112 & 145 & 116 & & 100 & 64 & 264 & & \\
\hline Other & & 125 & & 23 & 35 & 73 & 35 & 25 & 16 & & 21 & 66 & 48 & & \\
\hline Financial liabilities (Eurostat) & 70 & 83 & 66 & 84 & 126 & 50 & 170 & 127 & 100 & 102 & 116 & & & & \\
\hline $\begin{array}{l}\text { Measures of total financial weal } \\
\text { Byrne and Davis (2003) } \\
\text { Gross financial wealth as perce }\end{array}$ & $\begin{array}{l}\text { Ith }(F V) \\
\text { entage }\end{array}$ & ) from & other & tudies & & & & & & & & & & & \\
\hline $\begin{array}{l}\text { of GDP in } 2000 \\
\text { Bertaut }(2002)\end{array}$ & & & & 229 & 168 & 225 & & & & & 300 & & & & \\
\hline $\begin{array}{l}\text { Gross financial wealth in } 1998 \\
\text { NIGEM }\end{array}$ & & & & 340 & 240 & 370 & 600 & & & 230 & 480 & 520 & 460 & 250 & 380 \\
\hline Net financial wealth in $2002 \mathrm{Q}$ & & & & 250 & 150 & 270 & & & & & & 270 & 370 & & \\
\hline $\begin{array}{l}\text { Measures of stock market wealt } \\
\text { Byrne and Davis (2003) }\end{array}$ & th from & other: & studies & & & & & & & & & & & & \\
\hline $\begin{array}{l}\text { Household sector equity wealth } \\
\text { Bertaut (2002) }\end{array}$ & & & & 110 & 45 & 69 & & & & & 159 & & & & \\
\hline $\begin{array}{l}\text { Stock market capitalisation } \\
\text { as percentage of GDP in } 2001\end{array}$ & & & & 89 & 59 & 48 & 148 & & & 114 & 153 & 130 & 62 & 103 & 90 \\
\hline
\end{tabular}


APPENDIX 2

\section{THE US EVIDENCE ON WEALTH EFFECTS ON CONSUMPTION}

This section reviews the evidence of the effect of movements in asset wealth on US consumption. The US economy provides a particularly good "laboratory" for testing hypotheses about the relationships between asset prices and consumer spending because of the existence of the detailed quarterly Flow of Funds Accounts which provide a comprehensive picture of the aggregate balance sheet of the US household sector; the United States also has a number of useful sources of detailed micro-level information on household patterns of consumption and asset holdings.

This appendix first presents some estimates from aggregate regressions designed to estimate the MPC out of financial wealth and to review why various empirical studies have tended to arrive at different estimates of this parameter. Evidence from some studies based on micro-data is then briefly reviewed.

\section{A2.1. Aggregate time series evidence}

Empirical estimates of macroeconomic wealth effects have generally taken the aggregate budget constraint as their starting point, and then made a couple of simplifying assumptions regarding preferences and asset returns. For example, the most common applications of the permanent income hypothesis (PIH) usually assume that the rate of return on assets is constant. This assumption simplifies the aggregate budget constraint as

$$
A_{t+1}=(1+r)\left[A_{t}+Y_{t}-C_{t}\right]
$$

Repeated substitution of this expression yields a standard expression for the intertemporal budget constraint:

(A2.2) $\sum_{k=0}^{\infty} \frac{E_{t} C_{t+k}}{(1+r)^{k}}={ }_{A}+\sum_{k=0}^{\infty} \frac{E_{t} Y_{t+k}}{(1+r)^{k}}$.
Finally, a structural "consumption function" linking consumption to wealth and income is derived by making some assumptions about the expected evolution of consumption. For example, Robert Hall's (1978) seminal contribution assumed that consumers had quadratic utility and a discount rate equal to the rate of return on assets. This yielded the prediction that consumption should follow a random walk. Replacing all future expected values of consumption with today's value and re-arranging we get the most common "structural" form of the PIH:

(A2.3) $C_{t}=\frac{r}{1+r} A_{t}+\frac{r}{1+r} \sum_{k=o}^{\infty} \frac{E_{t} Y_{t+k}}{(1+r)^{k}}$.

This specification implies that households consume a constant proportion, $\frac{r}{1+r}$, of their total wealth, defined as the sum of current financial assets plus the discounted sum of current and expected future labour income. ${ }^{25}$

A re-formulation of this equation that has been used to estimate the MPC out of household wealth expresses the relationship in ratio form as

(A2.4) $\frac{C_{t}}{Y_{t}}=\alpha+\frac{r}{1+r} \frac{A_{t}}{Y_{t}}+\varepsilon_{t}$,

where ${ }_{t}$ is a mean-zero term reflecting current expectations about deviations of future labour income growth from its average levels. Note that we are referring to $Y$ as labour income to be consistent with the underlying budget constraint. Capital income is reflected in the budget constraint as the rate of return times the stock of invested assets, i.e. as $r\left[A_{t}+Y_{t}-C_{t}\right]$.

Figure A2.1 shows the fit of a simple ordinary least squares (OLS) regression for US quarterly data based on equation (A2.4), i.e. of a regression of the consumption to labour income ratio on a constant and the wealth-to-labour income ratio. The figure shows that movements

25 It should be noted that the prediction that households consume a constant proportion of total wealth is more robust to other assumptions about preferences than quadratic utility, although the exact formula here for the MPC out of wealth is specific to these preferences. 


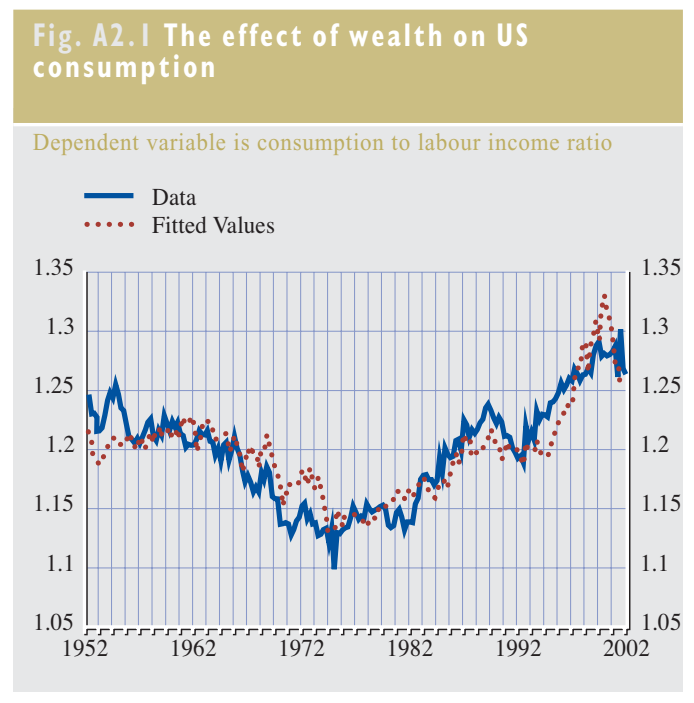

in wealth appear to explain most of the long-run swings in the consumption to income ratio: the adjusted $R^{2}$ for this regression is 0.77 . Charts of this sort have been used in a wide range of studies to illustrate how the growth in wealth in the $1990 \mathrm{~s}$ is a likely candidate for the substantial decline in the US saving rate over this period.

Table A2.1 reports some more details behind this regression, along with estimates from other implementations of this regression equation. All of the regressions employ an updated version of the quarterly dataset used in Palumbo, Rudd, and Whelan (2002). In each case the measure of asset wealth is total household net worth from the Flow of Funds Accounts (excluding the stock of consumer durables) as measured at the end of the previous quarter. ${ }^{26}$
The first row of the table shows that the estimate of the MPC out of wealth generated by the regression illustrated in Figure A2.1 is 6.1 cents per dollar of wealth. The second row uses a slightly different methodology: It replaces total consumption with a scaled-up version of consumption of non-durables and services. This approach is commonly taken in empirical consumption studies on the grounds that theories of short-run consumption dynamics apply best to a flow measure of consumption. This approach yields a relatively similar fit to the regression using total consumption, but has a slightly higher estimate of the MPC out of wealth of 6.9 cents per dollar. A number of aspects of these results are worth noting.

Deflation: The budget constraints - equations (A2.1) and (A2.4) - are each understood to be formulated in terms of real consumption, assets, income, and asset returns, i.e. each of the nominal variables in the nominal budget constraint have been deflated by the price index for total consumption. Because of this deflation by a common price index, the ratios of real variables in equation (A2.4) are identical to the ratios of the corresponding nominal variables. The regression in the second row (labelled "Method 1") follows this logic by replacing nominal consumption expenditures with a scaled version of nominal consumption of nondurables and services. This is the approach taken

26 The standard assumption about the budget constraint made in deriving consumption functions is that the consumption series in the budget constraint corresponds to total consumption expenditure. This implies that expenditure on durables is not considered asset accumulation in this case, and so theoretical consistency suggests that it should be excluded from the measure of wealth

\begin{tabular}{|c|c|c|c|c|}
\hline \multicolumn{5}{|c|}{ Standard errors in parentheses } \\
\hline Income Measure & Consumption measure & $\alpha$ & $\mu$ & Adjusted $\mathrm{R}^{2}$ \\
\hline Labour income & Total consumption & $0.84(0.03)$ & $0.061(0.005)$ & 0.77 \\
\hline Labour income & Scaled non-durables and services (Method 1) & $0.79(0.03)$ & $0.069(0.005)$ & 0.74 \\
\hline Labour income & Scaled non-durables and services (Method 2) & $0.98(0.07)$ & $0.041(0.012)$ & 0.26 \\
\hline Disposable income & Total consumption & $0.72(0.01)$ & $0.040(0.003)$ & 0.70 \\
\hline
\end{tabular}


by Palumbo, Rudd, and Whelan (2002). This method will provide an accurate approximation of the true relationship as long as the ratio of nominal consumption of non-durables and services to total nominal consumption expenditures is stable; Palumbo, Rudd, and Whelan (2002) show that this is the case for US data.

In contrast, however, many studies estimate consumption functions by continuing to deflate income and wealth by a price index for total consumption expenditure, but using a scaled version of real consumption of non-durables and services, so that consumption, income and assets are no longer all deflated by a common price index. Palumbo, Rudd, and Whelan show that this approach will only be accurate if the ratio of real consumption of non-durables to real consumption expenditure is stable, and that this assumption provides a very poor description of US data. They show that the total real US consumption expenditure has risen sharply over the post-war period relative to real consumption of non-durables and services. This implies that an empirical implementation of equation (A2.4) using this approach will suffer from significant approximation error and that this error will tend to increase over time, probably resulting in downward bias and instability in the estimated parameters. The third row of Table A2.1 (labelled "Method 2") shows that this approximation method does indeed result in a much poorer fit than the method based on nominal ratios, with the adjusted $R^{2}$ dropping to 0.26 .

Size of the MPC: Another interesting aspect of the regressions reported in the first two rows of Table A2.1 is that the size of the estimated MPC out of wealth, in the 0.06 to 0.07 range, is somewhat larger than has been reported in some other studies. For example, in a brief review of macroeconomic estimates, Poterba (2000) concludes that "values as high as 0.05 probably represent the upper range of the current estimates."

There appear to be two explanations for the higher estimates of the MPC reported here and in
Palumbo, Rudd, and Whelan (2002). The first is that many other studies have replaced total consumption expenditure with consumption of non-durables and services using the Method 2 approach just described. Because this approach adds a highly inaccurate approximation error to equation (A2.4), it is hardly surprising that it results in downward-biased estimates of the MPC: Table A2.1 reports that this method produces an MPC of 0.041 .

The second explanation is that some other studies have used disposable income instead of labour income in their empirical estimation. As noted above, this approach is inconsistent with the theory underlying the relationships between consumption, income and wealth: Essentially, it represents a double-counting of the effects of capital income. And, as shown in the fourth row of Table A2.1, this approach also results in a lower estimate of the MPC of exactly 0.04 . Note that if we use the slightly shorter sample employed in Davis and Palumbo (2001), this exercise can exactly replicate their preferred estimate of the MPC of 0.039 .

Upward bias (direct/indirect effects): Another issue that has been discussed in the literature on wealth effects concerns the potential correlation of wealth with the error term in the consumption regression. Poterba and Samwick (1995) phrase this debate as relating to whether estimated MPCs out of wealth reflect a direct effect of wealth on consumption or indirect effects resulting from the correlation of wealth with other unobservable variables influencing consumption. However, in terms of the framework underlying equation (A2.4), it does not appear that this problem represents a major source of bias in the estimates on the first two rows of Table A2.1. Theoretical considerations imply that the error in this regression relates to current expectations concerning future growth in labour income. This implies that estimates of the wealth effect will tend to be biased upwards if the wealth-to-income ratio, $\frac{A_{t}}{Y}$, tends to positively predict future increasés in labour income. However, regressions with our US 
quarterly dataset failed to uncover evidence that the wealth to income ratio "Grangercauses" labour income growth, so concerns over upward bias and "indirect effects" may be somewhat overstated.

Levels versus logs: Another specification issue is that the regressions in Table A2.1 estimate the MPC out of wealth, whereas a number of other studies (for example, Brayton and Tinsley, 1996, and Ludvigson and Steindel, 1999) estimate log-linear relationships between consumption, income, and wealth. These studies often translate their elasticity coefficients into estimated MPCs using sample averages of the wealth-to-income ratio. However, given the wide variations over time in the wealth-to-income ratio, and the theoretical priors indicating the superiority of direct estimation of the MPC, these log-linear estimates should probably be considered somewhat unsatisfactory.

Variable expected rates of return: We noted in deriving equation (A2.4) that this formulation, in which households consume a constant proportion, $\frac{r}{1+r}$, of their wealth depended on the assumption that the rate of return is constant. As Lettau and Ludvigson (2001) have stressed a more general approach, in which expected returns on assets are allowed to vary over time, predicts that the MPC out of wealth should move positively over time with expected future rates of return on assets. Thus, for example, if stock prices fall today because of a rise in the required equity premium, consumption need not decline because an increase in the MPC out of wealth may offset the decline in wealth itself.

While these ideas - that the MPC out of wealth may vary over time, and that consumption may react differently to asset price movements depending on their source - are intriguing and theoretically well-founded, at this point the empirical evidence for their relevance for the aggregate wealth effect on consumption is unclear. One interesting piece of evidence is the finding of Lettau and Ludvigson (2001) that a proxy for the (unobservable) ratio of consumption to total wealth (human plus tangible) appears to have forecasting power both for stock returns and for the excess returns of stocks over short-term bonds.

This result, however, provides us with little clue as to how important potential variations in expected returns may be in generating changes over time in the MPC out of wealth. On this issue, Figure A2.2 suggests that (despite the theoretical likelihood of variations over time in the MPC) the estimated wealth effect is actually quite stable. The figure shows recursive estimates of the regression reported on the second row of Table A2.1, i.e. it reports estimates from rolling regressions which add a data point for each period. Such regressions are often used as a diagnostic technique for uncovering parameter instability. The chart shows, however, that the estimated MPC from aggregate US data does not appear to have changed greatly over the past thirty years. ${ }^{27}$

27 This stability over time of the estimated MPC contrasts markedly with the conclusions of Ludvigson and Steindel (1999), who argue that the estimated wealth effect varies substantially over time. The principal reason for this difference is Ludvigson and Steindel's use of real consumption of non-durables together with measures of real income and wealth obtained by deflating by a price index for aggregate consumption. As discussed in the text, this approach adds a large and trending approximation error and so should be expected to produce unstable parameter estimates. Their study also adopts a log-linear specification in contrast to the linear specification estimated here.

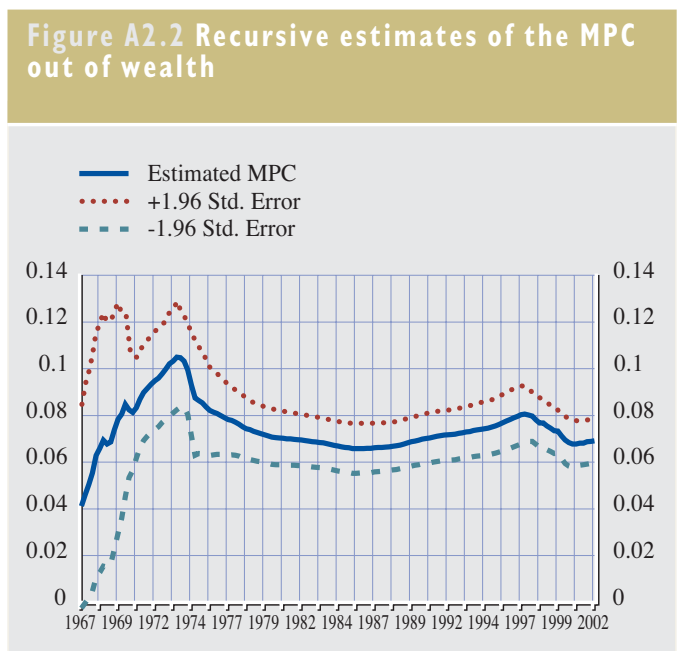


Estimates of the MPC using shorter movingsample windows display somewhat more variation over time, as would be expected, but there is limited evidence that these variations are related to changes in expected returns on financial assets. For example, Whelan (2003) shows that the MPC out of wealth does not appear to vary significantly over time due to fluctuations in dividend-price ratios, earningsprice ratios, yields spreads or other variables that have been considered useful predictors of financial asset returns. On balance, then, it appears that the jury is still out on the empirical importance of fluctuations in expected returns for the wealth effect.

Differences in MPCs across assets: Finally, Table A2.2 reports estimates from regressions that allow the MPC out of equity wealth to be different from that out of other wealth, i.e. it reports estimates of

$$
\text { (A2.5) } \frac{C_{t}}{Y_{t}}=\alpha+\mu_{e} \frac{A_{t}^{e}}{Y_{t}}+\mu_{o} \frac{A_{t}^{o}}{Y_{t}}+\varepsilon_{t}
$$

where $e$ denotes equity wealth and $o$ denotes other wealth. The table repeats a result reported previously in a number of studies (for instance, Brayton and Tinsley, 1996, and Davis and Palumbo, 2001) which is that the MPC out of equity wealth appears to be smaller than that out of other wealth. In fact, these results suggest that the MPC out of equity wealth is only about half that out of other wealth. Such a prediction cannot be derived from the type of "representative agent" models usually used in macroeconomics. However, it seems possible that these differences in the MPC across asset classes may reflect distribution issues. Equity wealth is more likely to be held by richer households, and studies have traditionally shown that such households have higher saving rates.

\section{Table A2.2 Empirical estimates of equation (A2.5) for US data}

\begin{tabular}{|c|c|c|c|c|}
\hline Income measure & Consumption measure & $\mu_{\mathrm{e}}$ & $\mu_{0}$ & Adjusted $\mathrm{R}^{2}$ \\
\hline Labour income & Total consumption & $0.054(0.002)$ & $0.102(0.004)$ & 0.87 \\
\hline Labour income & Scaled non-durables and services (Method 1) & $0.060(0.002)$ & $0.113(0.005)$ & 0.83 \\
\hline
\end{tabular}

Note: Sample is 1952:2 to 2002:2. See text for descriptions of Method 1 and Method 2. 


\section{APPENDIX 3}

\section{BALANCE SHEET CHANNEL}

\section{A3. I THEORETICAL CONSIDERATIONS}

The balance sheet channel stresses the potential impact that the quality of a company's balance sheet may have on investment spending decisions. A rise/fall in asset prices will improve/weaken the balance sheet position of a company, thus increasing/ reducing its ability to directly fund projects or provide collateral for external finance. In both cases, the risk that lenders face is reduced/ increased and the availability of credit increases/reduces. The importance of the link between balance sheet positions and investment can be seen in the slow recovery of the economy in many OECD countries from the 1990/91 recession. A number of analysts ${ }^{28}$ have attributed the slow recovery, in part, to the corporate sector's attempt to improve weak balance sheet positions coming from heavy corporate debt burden.

The recent literature on this channel builds on the theory of capital market imperfections such as asymmetric information and agency costs. The basic argument is that asymmetric information between lenders and borrowers induces a cost premium for funds raised externally in comparison to internal funds. This premium, called the external finance premium, reflects lenders' expected costs of monitoring and evaluating the quality of the company's investment opportunities, costs resulting from the fact that the borrower inevitably has better information than the lender or distortions in the borrower's behaviour coming from moral hazard. As a result, the cost of external finance (debt, equity) may be substantially higher than the cost of internal finance (cash flows, liquidity).

The balance sheet channel (often called the net worth channel) is based on the idea that the borrower's external finance premium depends on his financial position. In particular, many related studies focus on the borrower's net worth - defined as the borrower's liquid assets plus collateral value of illiquid assets - as a main state variable: the greater the level of net worth of the potential borrower (or, equivalently, the level of company's internal financing) the lower will be the premium on external finance. Shocks that affect net worth can be an initiating source of real fluctuations, through two transmission mechanisms:

i) One mechanism arises mainly from changes in cash flows. A negative shock reduces current output, lowers cash flows, and raises the company's need for external funds. Consequently, the expected agency cost and external finance premium rise, thus deferring investment and reducing output and cash flows in subsequent periods.

ii) The other mechanism operates through asset prices and the value of the collateral. The availability of credit for companies depends on the value of their assets. Here, an adverse shock reduces asset prices and the value of the collateral provided for loans, thus raising external finance premium and reducing investment.

An extensive part of the literature refers to the amplification and propagation of initial real or monetary shocks brought about by worsening credit market conditions (as reflected in borrowers' balance sheet positions), a phenomenon called the financial accelerator.

Bernanke and Gertler (1989) develop an RBC model in which the evolution of companies' net worth plays a critical role in macroeconomic dynamics, opening a channel through which the borrower's balance sheet position affects investment and output. A key virtue of this model is the inverse relationship between the potential borrower's wealth and the expected agency costs of the lender-borrower relationship, as described earlier. In this model, shocks to the economy are amplified

28 Bernanke and Lown (1991), pp. 206 and 211-212, and Tease (1993), p. 47. 
and propagated through their impact on borrowers' cash flows. An adverse exogenous productivity disturbance, for example, lowers current cash flows (income), reducing the ability of the company to finance investment with internal funds. Lower entrepreneurial wealth raises the external finance premium, thus impairing investment. Declining investment lowers economic activity and cash flows in subsequent periods, thus inducing a persistent investment downturn. An implication of this model is that the dynamic effects of such shocks may be asymmetric; specifically, the weaker the initial financial condition of the borrower, the more powerful is the propagation effect through cash flows. Additionally, during recessions, there is a reallocation of credit funds from low net worth to high net worth borrowers.

Apart from the changes in cash flows, variations in real and financial asset prices are a major channel for shocks to the net worth. In this direction, Kiyotaki and Moore (1997) develop a dynamic equilibrium model in which durable assets (land) are not only factors of production, but they also serve as collateral for loans. In their model, a small negative temporary shock to productivity lowers the value of the collateralised asset. This leads to tightened borrowing constraints and cutting backs on investment spending. The fall in spending lowers the value of existing assets and leads to a new round of reduced borrowing and spending, thus propagating the initial shock further through time. A key point of this study is the dynamic interaction between credit limits and asset prices, which turns out to be a powerful transmission mechanism by which the effects of shocks persist, amplify, and spread out.

Bernanke et al. (1999) develop a dynamic general equilibrium model, which exhibits a financial accelerator framework. The key innovation on investment is the relationship:

(A3.1) $E\left\{R_{t+1}^{K}\right\}=s\left(N_{t+1} / Q_{t} K_{t+1}\right) R_{t+1}$
Where $E\left\{R_{t+1}^{K}\right\}$ is the expected return on capital; $s()$ is a function of the ratio of the cost of external finance to the riskless rate, or external finance premium; $N_{t+1}$ represents net worth; $Q_{t} K_{t+1}$ are total financing requirements; and $R_{t+1}$ shows the opportunity cost of capital.

This expressions state that, in the presence of capital market imperfections, the premium on external funds depends inversely on the share of the company's capital investment financed by its own net worth, as measured by the ratio $\left(N_{t+1} / Q_{t} K_{t+1}\right)$.

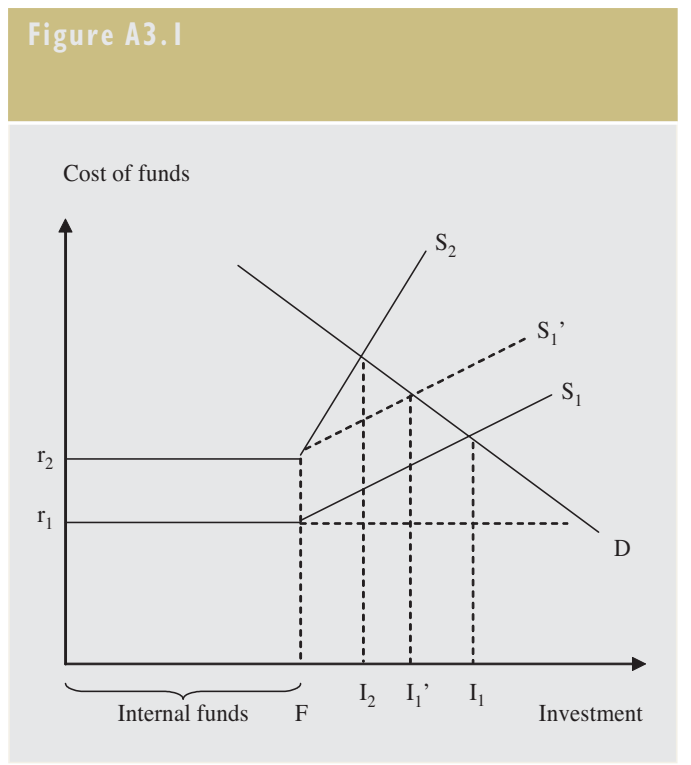

Figure A3. $1^{29}$ relates the cost of funds to the level of investment of the company, demonstrating these effects. For financing requirements, up to point $\mathrm{F}$, the company can use its own net worth (internal funds). The cost of these funds is $r_{1}$, which is the sum of the riskfree rate and a risk adjustment factor for the company. Without asymmetric information, external funds would also be available for the company at the rate $r_{1}$. However, asymmetric information means that, beyond $\mathrm{F}$, the company acquires external funds at a premium above $r_{1}$.

29 Oliner and Rudebusch (1996) 
The premium increases with the level of total finance raised externally, since higher debt means increased moral hazard and default risks. This link accounts for the upward slope of $\mathrm{S}_{1}$. In addition, the external premium increases with the level of the risk-free rate, as an increase in the interest rate lowers the present discounted value of the borrower's collateral and reduces the current cash flow, worsening the moral hazard problem. In Figure A3.1, an increase in the interest rate shifts the finance supply schedule from $S_{1}$ to $S_{2}$ (which is steeper than $\left.S_{1}{ }^{\prime}\right)$. The consequent fall in investment (from $\mathrm{I}_{1}$ to $\mathrm{I}_{2}$ rather than $\mathrm{I}_{1}{ }^{\prime}$ ) is magnified by the increase in the external finance premium. This example illustrates the potential link between investment demand and changes in net worth, implying that companies that can provide a higher collateral or finance a greater proportion of investment with internal funds will be likely to face a lower external finance premium.

\section{A3.2 EXISTING EMPIRICAL EVIDENCE}

A large part of the literature provides evidence that company investment is a function of liquidity and the quality of a company's balance sheet, as implied by the financial accelerator mechanism. A common perception is that differences in investment behaviour between companies should come from their respective access to capital markets. Generally, it has been found that investment is quite sensitive to financial variables like cash flows or the stock of liquid assets for those companies that face financial constraints. In these studies, the size of the company is widely considered as a proxy for capital market access, though other criteria such as the age of the company, the dividend pay-out or the coverage ratio are also used for this reason. Small companies are considered more likely to be affected by the balance sheet channel given their overall lower level of assets and the higher collateral requirements for loans (due to higher informational asymmetries). Consequently, a balance sheet weakening (e.g. due to a monetary policy tightening) might lower significantly the value of their collateral, thus leading to restricted credit access.

Fazzari et al. (1988) use data from US manufacturing companies for the period 19701984 to study the effect of cash flows on investment spending. They divide their sample based on the dividends to income ratio. Consistently with their perception, their results also show that the investment of companies which are believed a priori to be credit constrained (low-dividend companies) is more sensitive to fluctuations in their cash flow than high-dividend companies.

Gertler and Gilchrist (1994) used quarterly time series data for all US manufacturing companies, classified by size, to examine the response of small versus large companies to monetary tightening. They find that small companies account for a significant part of the consequent total manufacturing decline and that they play a prominent role in the slowdown of inventory investment. Looking for asymmetric effects, they find that the effects of monetary policy changes are greater on smallcompany variables during recessions (lowgrowth states). Their evidence also suggests that the coverage ratio (cash flows to interest expenses, an indicator of balance sheet quality) is positively related to inventory investment for small companies, but not for large companies.

Oliner and Rudebusch (1996) use Quarterly Financial Report data for the US manufacturing sector and divide companies into two classes: small and large companies. Their results show that after a monetary contraction, the association between cash flow (internal funds) and investment tightens significantly for small companies. In contrast, for large companies there was no change in this relationship.

In another paper, Guariglia (1998) uses data from a large panel of UK manufacturing companies for the period 1968-1991 to study the linkage between internal finance and inventory investment that appears to play an 
important role in business cycles. Companies are classified into more likely and less likely to be financially constrained in terms of the coverage ratio that is used as a proxy of the external finance premium. The author estimates several equations for inventory investment growth that include the coverage ratio or cash flows as explanatory variables for each group of companies. The results suggest that there is a significant link between the financial variables and inventory investment, stronger for companies with weak balance sheets, during recessions and periods of tight monetary policy.

Vermeulen (2000) uses the BACH-database for 10 manufacturing industries for the period 1983-1997 to study the presence of a financial accelerator in Germany, France, Italy, and Spain. He proxies the "weak balance sheet" term by using four different indicators: total debt as a fraction of total assets (leverage), short-term debt to current assets (liquidity), short-term debt as a fraction of total debt (market access) and the coverage ratio (credit worthiness). The results confirm the expectation that small company investment shows greater sensitivity to weak balance sheet positions, though there is no evidence that this effect increases during a downturn. Mediumsized companies are found to be influenced by balance sheet variables during downturns, rather than outside downturns. For large companies there is no evidence of an accelerator at all. Regarding country differences in the strength of the financial accelerator, the estimations show that balance sheet effects in downturns are stronger in France and Italy than in Germany and Spain.

Chatelain et al. (2001) use large company databases for Germany, France, Italy, and Spain for the period 1985-1999 to investigate the interest rate channel and the broad credit channel in the four larger euro-area countries. Standardised neo-classical investment regressions were used, in which investment is a function of sales, cash flow, and the user cost of capital. The authors find that in all these countries investment is quite sensitive to user cost, sales, and cash flow movements. They also find that only in Italy do smaller companies show greater sensitivity to cash flow movements (balance sheet conditions), although they argue that classification by size might not be a sufficient indicator for all countries.

Van Ees and Garretsen (1994) study the link between liquidity (internal funds) and business investment for a number of Dutch nonfinancial companies. Their estimations suggest that liquidity is of significant importance for Dutch business investment and that this impact is stronger than that found in related studies for the United States, the United Kingdom and Japan. With respect to the criteria used to deal with asymmetric information, the dividend policy, the size and the age of the companies do not seem to be important. However, the existence of close ties between banks and companies, which mitigates information problems, turns out to be very significant for the investment of Dutch companies. In a later study, Van Ees et al. (1998) also examine how debt constraints influence corporate investment of a panel of Dutch companies. They provide evidence that financial constraints influence the investment behaviour of these companies and show that such constraints are especially relevant for companies with low dividend pay-outs, while there was no similar evidence for smaller companies and the leverage criterion gave mixed results.

A number of related papers ${ }^{30}$ provide evidence for single euro area countries regarding the existence of a balance sheet (credit) channel as well as distribution effects across companies. For France (Chatelain and Tiomo, 2001), the existence of this channel is confirmed for companies facing a high risk of bankruptcy, companies in the equipment goods sector and companies using trade credit extensively, all of

30 Research conducted within the Monetary Transmission Network. 
which present high cash-flow sensitivity. For Italy (Gaiotti and Generale, 2001), the results also show that all financial variables (cash flow, stock of liquidity) affect investment decisions. This impact is found to be stronger for small companies and for companies with a higher share of intangible assets, which are difficult to evaluate and cannot be used as collateral. For Germany (von Kalckreuth, 2001), financially constrained companies, proxied in terms of lower-rated companies, are found to be more sensitive to financial variables. However, the sample split according to size presents no such sensitivity, possibly indicating the role of the house-banking system $^{31}$ in Germany. Here, the balance sheet channel seems to be of secondary importance compared to the interest rate channel. For Austria (Valderrama, 2001), the results support the existence of a credit channel as well as of heterogeneity across groups of firms. The liquidity ratio appears to be the most significant determinant of investment, though companies with a close relationship with a house bank are likely to become less dependent on internal funds. For Belgium (Butzen et al., 2001), the evidence supports the hypothesis of a credit channel as well as of distribution effects among companies of different size and sector. For Luxembourg (Lünnemann and Mathä, 2001), the idea that the strength of a company's balance sheet influences investment behaviour is also confirmed. Young companies seem to be more financially constrained, as their investment is more sensitive to changes in internally generated liquidity.

\section{A3.3 CONFIDENCE CHANNEL}

Stock market volatility may have indirect effects on the real economy through its impact on consumer and business confidence. A fall (rise) in stock prices may signal poor (good) economic prospects, altering market participants' assessments of economic risks. Consequently, their incentive to spend will be reduced (increased), thus affecting consumption and corporate investment. For example, a large fall in stock prices may force companies, even those that have not issued stocks, to revise their profit expectations and reduce or postpone investment. In addition, falling stock prices and weak business confidence may increase investors' risk aversion. Investors may subsequently reduce their holdings in risky assets and ask for higher risk premiums, which may be passed on to business in terms of higher interest rates and lower equity prices, with a negative impact on investment. ${ }^{32}$

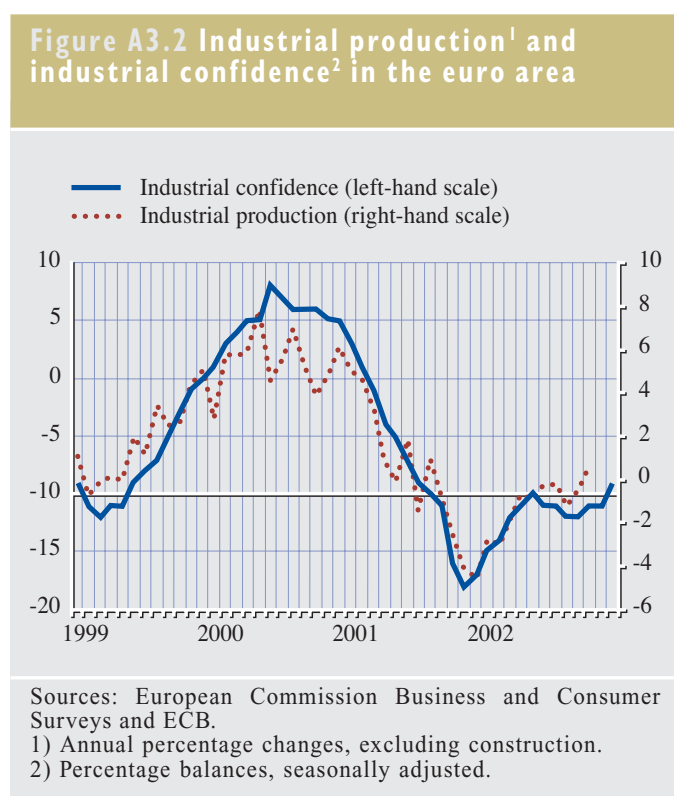

This channel is consistent with the forwardlooking nature of stock prices and their leading indicator property for real economic activity that has been empirically found for the euro area. As stock prices reflect market participants' expectations for future corporate earnings, which are closely related to economic activity, stock prices help predict future economic growth.

While the potential mechanism of a confidence effect on the economy is comprehensible, the

31 This refers to the establishment of a long-term lending relationship between a company and a bank, called the house bank. This practice may help companies overcome liquidity constraints, thus weakening the balance sheet channel. 32 IMF, World Economic Outlook, December 2001. 
assessment of this effect is rather complicated. This is because confidence is a feeling and not an action, which is difficult to assess quantitatively. Generally, confidence is measured by surveys that include questions on the assessment of current conditions and future expectations. Several of the constructed indicators have been found to possess good leading indicator properties for the business cycle and can be considered as adequate for research on macroeconomic issues.

Figure A3.2 depicts industrial confidence and industrial production for the period 1999-2002 in the euro area. In particular, industrial confidence is found to be closely linked to the business cycle component (industrial production $)($ correlation $=0.93)$.

Figure A3.3 depicts the development of the EuroStoxx broad index, industrial confidence and consumer confidence in the euro area for the same period. In several periods confidence follows similar patterns to the stock price measure (with high positive correlation in both cases). In particular, the turning points of the stock market index tend to lead the turning points of confidence, showing that stock prices and confidence co-move quite closely

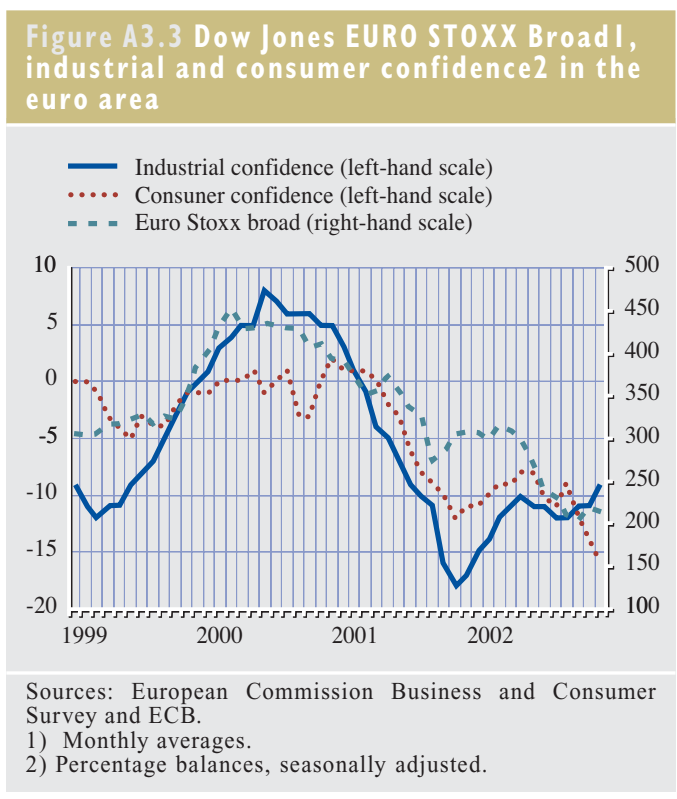

(especially in the case of industrial confidence).

Arnold et al. (2002) and Jansen and Nahuis (2003) confirm the predictive power of share prices for confidence indicators. They find that equity prices lead confidence indicators in a large number of European countries and the United States. This link, however, may simply reflect more direct wealth and cost of capital effects and does not necessarily imply a causal relationship between stock prices and confidence.

Jansen and Nahuis (2003) find empirical support for causality from stock market to confidence. They also suggest that this relationship is driven by expectations about economy-wide conditions rather than personal finances and that the confidence channel is a separate transmission channel and not an adjunct to conventional wealth effects. This conclusion may hold for studies based on micro-level data, although, in the case of aggregate time-series data, the estimation of wealth effects also reflects expectations about the future.

In this context, confidence could be a catalyst for an impact from stock prices on consumption and investment spending. It is, however, difficult to disentangle empirically the relative indirect impact of confidence on actual spending behaviour. In this regard, Figure A3.4 depicts industrial confidence in relation to investment growth, suggesting that there were periods when investment growth did not follow significant movements in industrial confidence.

Impulse response analysis (by the ECB) of the relationship between stock prices and confidence indicators, indicates that the effect of stock price changes is reflected after some time in confidence indicators and dies out only after several years. The effects on industrial confidence appear and die out faster than those on consumer confidence. Generally, in this 


\section{Table A3.I Impact of confidence indices on the growth in real GDP}

(\% of GDP, unless otherwise indicated)

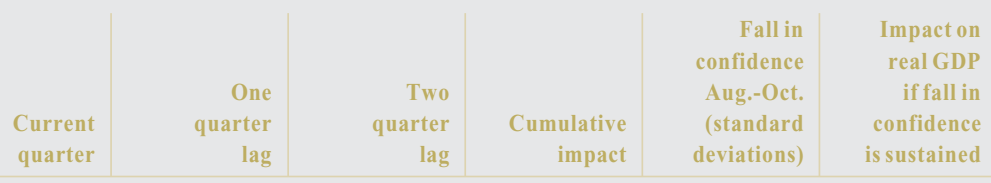

Impact of a one standard deviation fall in the monthly change in business confidence on real GDP

United States

$-0.18 * * *$

$-0.10 * *$

$-0.08 *$

$-0.07 *$

$-0.31$

$-0.09 * * \quad-0.23$

Japan

Germany

$-0.14 *$

$-0.04$

$-0.07$

$-0.06$

$-0.05$

$-0.27$

$-0.10 * * * \quad-0.05$

France

$-0.12 * * *$

$-0.02$

$-0.01$

$-0.20$

$-0.09 *$

United Kingdom

$-0.11 * *$

$-0.08^{*}$

$-0.02-0.15$

$-0.04 * \quad-0.23$

Canada

$-0.05$

-0.11 *

$-0.06$

-0.23
-0.22

$\begin{array}{rr}3.2 & -1.0 \\ 4.2 & -1.0 \\ \text { n.a. } & \text { n.a. } \\ 3.7 & -0.7 \\ 1.9 & -0.3 \\ 3.0 & -0.7 \\ 0.5 & -0.1 \\ \text { n.a. } & \text { n.a. }\end{array}$

Impact of a one standard deviation fall in the monthly change in consumer confidence on real GDP

United States

- Conference Board

$-0.14 * * *$

$-0.09 *$

$-0.08 *$

$-0.15 * * *$

$-0.37$

$-0.09 * * \quad-0.27$

5.0

$-1.9$

Source: IMF, World Economic Outlook, December 2001.

Notes: Three asterisks indicate the results are significant at the $1 \%$ level, two asterisks at the $5 \%$ level, and one asterisk the $10 \%$

level. The coefficients were calculated in such a way that they would be cumulated over time.

analysis, the adjustment of confidence to permanent stock price changes seems rather slow and limited.

Several analyses of the impact of consumer confidence on spending in the United States and the United Kingdom find that it has some explanatory power, but the available evidence for the euro area and business confidence are rather scarce. Table A3.1 summarises the results of an analysis undertaken by the staff of the IMF on the business and consumer confidence indices. The exercise looked into the impact of confidence indices on growth in real GDP for Canada, France, Italy, Japan, the United Kingdom and the United States. The results suggest that in the United States both business and consumer confidence indicators provide useful information about output of the current and the following two quarters. For the other countries (except Canada), only the business confidence series seem to provide such information. It was also shown that, if the fall in confidence was sustained, output could fall by one percentage point in the United States, 0.7 in Germany and Italy, 0.3 in France and 0.1 in the United Kingdom. In addition, it was found that when other variables (stock price change, interest rate movements, and last period's growth) were taken into consideration, the confidence effect on output growth was generally reduced. 


\section{REFERENCES}

Alessie, R.J.M., S. Hochguertel and A. Van Soest (2002), "Household portfolios in the Netherlands", in L. Guiso, M. Haliassos and T. Jappelli, Household Portfolios, The MIT Press, Cambridge, MA, pp. 341-388.

Alonso, C. and S. Bentolila (1992), “The relationship between investment and Tobin's Q in Spanish industrial firms", Documento de Trabajo n 9203, Banco de España.

Andersen, M. and R. Subbaraman (1996), "Share prices and investment", Reserve Bank of Australia Research Discussion Paper No. 9610.

Aoki, K., J. Proudman and G. Vlieghe (2002), "Houses as collateral: Has the link between the house prices and consumption in the UK changed", Economic Policy Review, 8(1) Federal Reserve Bank of New York, May.

Arnold, I., P. van Els and J. de Haan (2002), "Wealth effects and monetary policy", De Nederlandsche Bank Research Memorandum No. 719.

Assarsson, B., C. Berg and P. Jansson, (2004) "Investment in Swedish Manufacturing: Analysis and Forecasts", Empirical-Economics, 29(2), pp. 261-80.

Attanasio, O. (1995), "Intertemporal Allocation of Consumption: Theory and Evidence", Carnegie Rochester Conference Series on Public Policy, 42(0), pp. 39-89.

Attanasio, O., J. Banks, C. Meghir and G. Weber (1999), "Humps and bumps in lifetime consumption", Journal of Business and Economic Statistics, 17(1), pp. 22-35.

Attanasio, O., J. Banks and S. Tanner (1998), “Asset Holdings and Consumption Volatility", NBER Working Paper No. 6567, May.

Audretsch, D.B. and J.A. Elston (2002), "Does Firm Size Matter? Evidence on the Impacts of Liquidity Constraints on Firm Investment Behavior in Germany", International Journal of Industrial Organization, 20(1), pp. 1-17.

Babeau, A. and T. Sbano (2002), "Household wealth in the national accounts of Europe, the United States and Japan", presented at the OECD Meeting of National Accounts Experts, October.

Baker, M., J. Stein and J. Wurgler (2002), "When does the market matter? Stock prices and the investment of equity-dependent firms", NBER Working Paper No. 8750.

Balmaseda, M. and P. Tello (2002), “ ¿Han cambiado los determinantes del consumo privado en España?" (Have determinants of consumption changed in Spain?), Situación Española, BBVA, July, pp. 33-39.

Banco do Portugal (2003), "Request for information on research on wealth effects on consumption in EU countries. 2000 Household Wealth Survey", January. 
Barot, B. and Z. Yang (2002), "House Prices and Housing Investment in Sweden and the UK: Econometric Analysis for the Period 1970-1998", Review of Urban \& Regional Development Studies, 14, pp. 189-216.

Bayoumi, T. and H. Edison (2002), “Is Wealth Increasingly Driving Consumption?”, IMF Working Paper, October.

Bernanke, B. and M. Gertler (1989), "Agency Costs, Net Worth and Business Fluctuations", American Economic Review, 79, pp. 14-31.

Bernanke, B.S. and C.S. Lown (1991), “The Credit Crunch", Brookings Papers on Economic Activity, 0(2), pp. 204-39.

Bernanke, B., M. Gertler and S. Gilchrist (1999), "The Financial Accelerator in a Quantitative Business Cycle Framework", in J.B. Taylor and M. Woodford (eds.), Handbook of Macroeconomics, Volume 1C, Handbooks in Economics, vol. 15., Amsterdam, New York and Oxford: Elsevier Science, North-Holland, pp. 1341-93.

Bertaut, C. (2002), "Equity Prices, Household Wealth, and Consumption Growth in Foreign Industrial Countries: Wealth Effects in the 1990s", Federal Reserve Board International Finance Discussion Paper No. 724.

Blanchard, O.J. (1985), "Debt, deficits, and finite horizons", Journal of Political Economy, 93, pp. 223-247.

Blanchard, O.J, C. Rhee and L.H. Summers (1993), "The stock market, profit and investment", Quarterly Journal of Economics, February, pp. 115-136.

Blundell, R., M. Browning and C. Meghir (1994), "Consumer Demand and the Life-Cycle Allocation of Household Expenditures", Review of Economic Studies, 61(1), pp. 57-80.

Bond, S. and J. Cummins (2001), "Noisy share prices and the Q model of investment", IFS Working Papers W01/22, Institute for Fiscal Studies.

Boone, L., C. Giorno and P. Richardson (1998), "Stock Market Fluctuations and Consumption Behaviour: Some Recent Evidence”, OECD Economic Department Working Papers No. 208.

Boone L., N. Girouard and I. Wanner (2001), "Financial market liberalisation, wealth and consumption”, OECD Economics Department Working Papers No. 308.

Brady, P.J., G.B. Canner and D.M. Maki (2000), "The Effects of Recent Mortgage Refinancing”, Federal-Reserve-Bulletin, 86(7), pp. 441-50.

Brav, A., G.M. Constantinides and C.C. Geczy (1999), "Asset Pricing with Heterogeneous Consumers and Limited Participation: Empirical Evidence”, Rodney L. White Center for Financial Research Working Paper No. 23.

Brayton, F. and P. Tinsley (1996), “A Guide to FRB/US: A Macroeconomic Model of the United States", Federal Reserve Board Finance and Economics Discussion Series No. 42. 
Butzen, P., C. Fuss and P. Vermeulen (2001), "The interest rate and credit channel in Belgium: an investigation with micro-level firm data", ECB Working Paper No. 107.

Butzen, P., C. Fuss and P. Vermeulen (2003), "Business investment and monetary transmission in Belgium”, in Angeloni I., A. Kashyap and B. Mojon (eds.), "Monetary Policy Transmission in the Euro Area", United Kingdom, pp. 162-172.

Byrne, J. and E. Philip Davis (2003), "Disaggregate Wealth and Aggregate Consumption - An investigation of empirical relationships for the G7", Oxford Bulletin of Economics and Statistics, 65(2), pp. 197-220(24).

Campbell, J.Y. (1996), “Understanding Risk and Return”, Journal of Political Economy, 104, pp. 298-345.

Campbell, J.Y. (2001), "Consumption-Based Asset Pricing”, unpublished paper, Harvard University.

Campbell, J.Y. and J.H. Cochrane (1999), "By force of habit: A consumption-base explanation of aggregate stock market behaviour”, Journal of Political Economy, 107, pp. 205-251.

Campbell, J.Y. and M. Goto (2002), “Efficient Tests of Stock Return Predictability”, unpublished paper, Harvard University.

Campbell, J.Y., A.W. Lo and C. MacKinlay (1997), The Econometrics of Financial Markets, Princeton University Press, Princeton, NJ.

Campbell, J.Y. and N.G. Mankiw (1989), "Consumption, Income, and Interest Rates: Reinterpreting the Time Series Evidence", in O.J. Blanchard and S. Fisher (eds.), NBER Macroeconomic Annual, pp. 185-216.

Campbell, J.Y. and R.J. Shiller (1988), “The Dividend-Price Ratio and Expectations of Future Dividends and Discount Factors", Review of Financial Studies, 1, pp. 195-227.

Campbell, J.Y. and L.M. Viceira (1999), "Consumption and portfolio decisions when expected returns are time varying”, The Quarterly Journal of Economics, May, pp. 433-495.

Carroll, C. and M. Kimball (1996), "On the Concavity of the Consumption Function", Econometrica, 64, pp. 981-992.

Case, K.E., J.M. Quigley and R.J. Shiller (2001), “Comparing Wealth Effects: The Stock Market Versus The Housing Market", NBER Working Paper No. 8606.

Chatelain J.B., A. Generale, I. Hernando, U. von Kalckreuth and P.Vermeulen (2003), "Firm investment and monetary transmission in the euro area", in Angeloni I., A. Kashyap and B. Mojon (eds.), "Monetary Policy Transmission in the Euro Area", Cambridge University Press, United Kingdom, pp. 133-161.

Chatelain, J.B. and A. Tiomo (2001), "Investment, the cost of capital, and monetary policy in the nineties in France: a panel data investigation”, ECB Working Paper No. 106. 
Chatelain, J.B. and A. Tiomo (2003), "Monetary policy and corporate investment in France", in Angeloni I., A. Kashyap and B. Mojon (eds.), "Monetary Policy Transmission in the Euro Area”, Cambridge University Press, United Kingdom, pp. 187-197.

Chirinko, R.S. (1993), "Business Fixed Investment Spending: Modeling Strategies, Empirical Results, and Policy Implications", Journal of Economic Literature, 31(4), pp. 1875-1911.

Chirinko, R. S and H. Schaller (2001), "Business Fixed Investment and "Bubbles": The Japanese Case", American Economic Review, 91(3), pp. 663-80.

Choi, J.J., S. Hauser, and K.J. Kopecky (1999), "Does the Stock Market Predict Real Activity? Time Series Evidence from the G-7 Countries", Journal of Banking and Finance, 23, pp. 17711792.

Clapham, E., A. Hyytinen and K. Takala (2002), "Household Wealth, Credit and Consumption: Evidence from Finland and Sweden”, mimeo, Bank of Finland.

Cochrane, J.H. (2001), Asset Pricing, Princeton University Press, Princeton, NJ.

Constantinides, G. (1990), "Habit formation: A solution to equity premium puzzle", Journal of Political Economy, 98, pp. 519-543.

Darby, J., J. Ireland, C. Leith and S. Wren-Lewis (1999), “COMPACT: a rational expectations, intertemporal model of the United Kingdom economy”, Economic Modelling, 16, pp. 1-52.

Davis, M., and M.G. Palumbo (2001), “A Primer on the Economics and Time Series Econometrics of Wealth Effects", Federal Reserve Board Finance and Economics Discussion Series No. 09.

De Nederlandsche Bank (1999), "The Dutch Housing and Mortgage Markets: A risk analysis" Boletín Económico, November, Quarterly Bulletin, September.

Danmarks Nationalbank (2003), MONA - A quarterly model of the Danish Economy.

Deutsche Bundesbank (2002), "The impact of stock prices on private consumption - wealth effects in Germany", mimeo.

Dynan, K. and D.M. Maki (2001), “Does Stock Market Wealth Matter for Consumption?", Federal Reserve Board Finance and Economics Discussion Series No. 23.

Dynan, K., J. Skinner and S. Zeldes (2000), "Do the rich save more?", NBER Working Paper No. 7906.

Edison, H. and T. Sløk (2001), "Wealth Effects and the New Economy", IMF Working Paper No. 77.

Elder R. and J. Power (2002), "The role of housing wealth in the consumption equation", mimeo, Bank of England. 
van Ees, H. and H. Garretsen (1994), "Liquidity and Business Investment: Evidence from Dutch Panel Data", Journal of Macroeconomics, 16, pp. 613-627.

van Ees, H., H. Garretsen, L. de Haan and E. Sterken (1998), "Investment and Debt Constraints: Evidence from Dutch Panel Data", in S. Brakman, H. van Ees and S.K. Kuipers (eds.), Market Behaviour and Macroeconomic Modelling, MacMillan, London, pp. 159-179.

Engelhardt, G.V. (1995), "House Prices and Home Owner Saving Behavior", NBER Working Paper No. 5183.

Estrada, A., J.L. Fernández, E. Moral and A.V. Regil (2004), “A Quarterly Macroeconometric Model of the Spanish Economy”, Banco de España, Documentos de Trabajo nº413.

European Central Bank (2003), Structural Factors in the EU Housing Markets.

Fama, E.F. (1990), "Stock Returns, Expected Returns, and Real Activity", The Journal of Finance, 45, pp. 1089-1108.

Fama, E.F. and K.R. French (1988), "Dividend Yields and Expected Stock Returns", Journal of Financial Economics, 22, pp. 3-27.

Faruquee, H., P. Isard, D. Laxton, E. Prasad and B. Turtelboom (1998), "MULTIMOD Mark III, the core dynamic and steady-state models", IMF Occasional Paper No. 164.

Fazzari, S., G. Hubbard and B. Petersen (1988), "Financing Constraints and Corporate Investment", Brookings Papers on Economic Activity, 1, pp. 141-195.

Fuhrer, J.C. (2000), "Habit Formation in Consumption and its Implications for Monetary-Policy Models", American Economic Review, 90(3), pp. 367-390.

Gaiotti, E. and A. Generale (2001) "Does monetary policy have asymmetric effects? A look at the investment decisions of Italian firms", ECB Working Paper No. 110.

Gaiotti. E. and A. Generale (2003) "Monetary policy and firms' investment in Italy", in Angeloni I., A. Kashyap and B. Mojon (eds.), "Monetary Policy Transmission in the Euro Area", United Kingdom, pp. 198-211.

Gertler, M. and S. Gilchrist (1994), "Monetary policy, business cycles and the behavior of small manufacturing firms", The Quarterly Journal of Economics, 109, pp. 309-340.

Girouard, N. and S. Blöndal (2002), "House prices and economic activity", OECD Working Paper No. 279.

Guiso, L., M. Haliassos and T. Jappelli (2002), Household Portfolio, MIT Press.

Guiso, L., M. Paiella and I. Visco (2004), "Do capital gains affect consumption? Estimates of wealth effects from Italian households' behaviour", mimeo. 
Goyal, V.K. and T. Yamada (2004), "Asset prices, Financial Constraints and Investment: Evidence from Japan”, Journal of Business, 77(1), pp. 175-200.

Guariglia, A. (1998), "The effects of financial constraints on inventory investment: evidence from a panel from UK firms", Economica, 66, pp. 43-62.

Hall, R. (1978), "Stochastic Implications of the Life Cycle-Permanent Income Hypothesis: Theory and Evidence", Journal of Political Economy, 96, pp. 971-87.

Hamburg, B., M. Hoffmann and J. Keller (2005), "Consumption, wealth and business cycle: Why is Germany different?”, Deutsche Bundesbank, Economic Research Center Discussion Paper No. 1 16/2005.

Hayashi, F. (1982a), "Tobin's marginal and average Q: A Neoclassical interpretation", Econometrica, 50(1), pp. 213-244.

Hayashi, F. (1982b), "The Permanent Income Hypothesis: Estimation and Testing by Instrumental Variables", Journal of Political Economy, 90, pp. 895-915.

Hodrick, Robert (1992), "Dividend Yields and Expected Stock Returns: Alternative Procedures for Inference and Measurement", Review of Financial Studies, 5, pp. 357-386.

International Monetary Fund (2000), “Asset Prices and the Business Cycle”, World Economic Outlook, May.

International Monetary Fund (2001), World Economic Outlook, December, Chapter II.

International Monetary Fund (2002), “Is wealth increasingly driving consumption?", World Economic Outlook, April, Chapter II.

Jansen, J.W. and J.N. Nahuis (2003), "The stock market and consumer confidence: European evidence", Economics Letters, 79, pp. 89-98.

Juster, F.T., J. Lupton, J.P. Smith and F. Stafford (1999), "Savings and wealth; then and now", mimeo, University of Michigan, October.

Kenny, G. (2003), "Asymmetric adjustment costs and the dynamics of housing supply", Economic Modelling, 20, pp. 1097-1111.

Kiyotaki, N. and J. Moore (1997), "Credit cycles”, Journal of Political Economy, 105(2), pp. 211 248.

von Kalckreuth, U. (2001), "Monetary transmission in Germany: new perspectives on financial constraints and investment spending”, ECB Working Paper No. 109.

Labhard, V., G. Sterne and C. Young (2005), "The wealth effects on consumption in industrialised countries", Bank of England working paper, (forthcoming). 
Lamont, O. (1998), “Earnings and Expected Returns", Journal of Finance, 53, pp. 1563-1587.

LeRoy, S. and R. Porter (1981), "The Present Value Relation: Tests Based on Variance Bounds", Econometrica, 49, pp. 555-557.

Lettau, M. and S.C. Ludvigson (2002), "Understanding Trend and Cycle in Asset Values", revised July, (http://www.econ.nyu.edu/user/ludvigsons/eqprem1.pdf).

Lettau, M. and S.C. Ludvigson (2001), "Consumption, Aggregate Wealth and Expected Stock Returns", Journal of Finance, 56(3), pp. 815-849.

Lettau, M., S. Ludvigson and N. Barczi (2001), "A Primer on the Economics and Time Series Econometrics of Wealth Effects: A Comment", Federal Reserve Bank of New York, (http:// www.econ.nyu.edu/user/ludvigsons).

Lewellen, J.W. (2001), "Predicting Returns With Financial Ratios", unpublished paper, MIT Sloan School of Management.

Ludvigson, S. and C. Steindel (1999), "How Important Is the Stock Market Effect on Consumption?", Federal Reserve Bank of New York Policy Review, 2(5), pp. 29-51.

Ludvigson, S., C. Steindel and M. Lettau (2002), "Monetary Policy Transmission through the Consumption-Wealth Channel", FRBNY Economic Review, May, pp. 117-133.

Ludwig, A. and T. Sløk (2001), "Impact of Stock Prices and House Prices on Consumption in OECD Countries", IMF Working Paper No. 1.

Lünnemann, P. and T. Mathä (2001), "Monetary transmission: empirical evidence from Luxembourg firm level data”, ECB Working Paper No. 111.

Lünnemann, P. and T. Mathä (2003), "Monetary transmission: empirical evidence from Luxembourg firm level data", in Angeloni I., A. Kashyap and B. Mojon (eds.), "Monetary Policy Transmission in the Euro Area", Cambridge University Press, United Kingdom, pp. 212-220.

Maclennan, D., J. Muellbauer and M. Stephens (1998), “Asymmetries in housing and financial market institutions and EMU”, Oxford Review of Economic Policy, 14, pp. 54-80.

Maki, D.M. and M.G. Palumbo (2001), "Disentangling the Wealth Effect - A Cohort Analysis of Household Saving in 1990s", Federal Reserve Board Finance and Economics Discussion Series No. 23.

Mankiw, N.G. and S.P. Zeldes (1990), "The Consumption of Stockholders and NonStockholders", NBER Working Paper No. 3402.

Mauro, P. (2000), "Stock Returns and Output growth in Emerging and Advanced Economies", IMF Working Paper No. 89. 
Mehra, Y.P. (2001), "The Wealth Effect in Empirical Life-Cycle Consumption Equations", Federal Reserve Bank of Richmond Economic Quarterly, 87(2), pp. 45-68.

Merrigan, P. and M. Normandin (1996), "Precautionary Saving Motives: An Assessment from UK Time Series of Cross-Sections”, Economic Journal, 106(438), pp. 1193-1208.

Millard and J. Power (2002), "The effect of shocks to equity prices on consumption", iManage No. 181748 .

Modigliani, F. (1977), "Consumer Spending and Monetary Policy: The Linkages", Federal Reserve Bank of Boston Conference Series, 5, pp. 9-84.

Morck, R., A. Schleifer and R.W. Vishny (1990), "Stock Market and Investment: Is the Market a Sideshow”, Brookings Papers on Economic Activity, 2, pp. 157-202.

Muellbauer, J. (2004), "Property and Land, Taxation and the Economy after the Barker Review", mimeo, Nuffield College, Oxford, July.

Muellbauer, J. and R. Lattimore (1995), "The consumption function: A theoretical and empirical overview", in M.H. Pesaran and M. Wickens (eds.), Handbook of Applied Econometrics: Macroeconomics, Blackwell Publishing, Oxford, pp. 221-311.

National Bank of Belgium (2003), "Answer to the request for information on research on wealth effects on consumption in EU countries", January.

Oliner, S. and G. Rudebusch (1996), "Is there a broad credit channel for monetary policy?", Federal Reserve Bank of San Francisco Economic Review, 1, pp. 3-13.

Otto, M.W. (1999), “Consumer Sentiment and the Stock Market”, Federal Reserve Board Finance and Economics Discussion Series No. 60.

Palumbo, M., J. Rudd and K. Whelan (2002), "On Relationships between Real Consumption, Income, and Wealth", Federal Reserve Board Finance and Economics Discussion Series No. 38.

Paiella, M. (2003), "Does Wealth Affect Consumption? Evidence for Italy", mimeo, Bank of Italy, Research Department.

Parker, J.A. (1999a), "Spendthrift in America? On Two Decades of Decline in the US Saving Rate", in B. Bernanke and J. Rotemberg (eds.), NBER Macroeconomics Annual, The MIT Press, Cambridge, MA.

Parker, J.A. (1999b), “The Reaction of Household Consumption to Predictable Changes in Social Security Taxes", American Economic Review, 89(4), pp. 959-973.

Pesaran, M.H, Y. Shin and R.P. Smith (1999), "Pooled mean group estimation of dynamic heterogeneous panels", Journal of the American Statistical Association, 94, pp. 621-634. 
Poterba, J. (2000), “Stock Market Wealth and Consumption”, Journal of Economic Perspectives, 14(2), pp. 99-119.

Poterba, J. and A. Samwick (1995), "Stock Ownership Patterns, Stock Market Fluctuations, and Consumption", Brookings Papers on Economic Activity, 2, pp. 295-372.

Reifschneider, D., R. Tetlow and J. Williams (1999), “Aggregate Disturbances, Monetary Policy and the Macroeconomy: The FRB/US Perspective", Federal Reserve Bulletin, 85, pp. 1-19.

Romer, C. (1990), "The Great Crash and the Onset of the Great Depression", Quarterly Journal of Economics, 105, pp. 597-624.

Rudd, J. and K. Whelan (2002), "A Note on the Cointegration of Consumption, Income, and Wealth”, Federal Reserve Board Finance and Economics Discussion Series No. 53.

Sefton, J.A. and J.W. in't Veld (1999), "Consumption and Wealth: An International Comparison”, Manchester-School, 67(4), pp. 525-44.

Shiller, R.J. (1981), "Do Stock Prices Move Too Much to be Justified by Subsequent Changes in Dividends?", American Economic Review, 71, pp. 421-436.

Shiller, R. (1984), “Stock Prices and Social Dynamics," Brookings Papers on Economic Activity, 2, pp. 457-498.

Starr-McCluer, M. (1998), "Stock Market Wealth and Consumer Spending", Federal Reserve Board Governors, April.

Smets, F. and R. Wouters (2002), "An estimated stochastic dynamic general equilibrium model of the euro area”, ECB Working Paper No. 171.

Sundaresan, S. (1989), "Intertemporally dependent preferences and the volatility of consumption wealth, Review of Financial Studies 2, pp. 73-89.

Tease, W. (1993), “The Stock Market and Investment”, OECD Economic Studies, 20, pp. 41-63.

Thaler, R. (1994), "Psychology and Saving Policies", American Economic Review, 84, pp. 186192.

Thomas, P. (2002), "Share ownership and household spending in the United Kingdom", I-manage No. 160692.

Tobin, J. (1969), “A general equilibrium approach to monetary theory”, Journal of Money, Credit and Banking, 1, pp. 15-29.

Valderrama, M.T. (2001), "Credit channel and investment behavior in Austria: a microeconometric approach", ECB Working Paper No. 108. 
Valderrama, M.-T. (2003), "The role of trade credit and bank lending relationships in the transmission mechanism in Austria", in Angeloni I., A. Kashyap and B. Mojon (eds.), "Monetary Policy Transmission in the Euro Area", Cambridge University Press, United Kingdom, pp. 221-232.

Vermeulen, P. (2000), "Business fixed investment: Evidence of a financial accelerator in Europe", ECB Working Paper No. 37.

Vissing-Jørgensen, A. (1999), "Limited Stock Market Participation and the Equity Premium Puzzle", mimeo, University of Chicago, December.

Whelan, K. (2003), "Market Valuations and the Wealth Effect on Consumption", paper presented at The Irish Economic Association $17^{\text {th }}$ Annual Conference.

Willman, A. (2003), "Consumption, habit persistence, imperfect information and the lifetime budget constraint”, ECB Working Paper No. 251.

Willman, A. and A. Estrada (2002), "The Spanish block of the ESCB-Multi-Country Model", Documento de Trabajo n ${ }^{\circ}$ 0212, Banco de España, and ECB Working Paper No. 149.

Willman, A., M. Kortelainen, H.-L. Männistö and M. Tujula (2000), “The BOF5 macroeconomic model of Finland, structure and dynamic microfoundations", Economic Modelling, 17, pp. 275-303.

Zeldes, S.P. (1989), "Optimal Consumption with Stochastic Income: Deviations from Certainty Equivalence”, Quarterly Journal of Economics, 104, pp. 275-298. 



\section{EUROPEAN CENTRAL BANK}

OCCASIONAL PAPER SERIES

1 "The impact of the euro on money and bond markets" by J. Santillán, M. Bayle and C. Thygesen, July 2000.

2 "The effective exchange rates of the euro" by L. Buldorini, S. Makrydakis and C. Thimann, February 2002.

3 "Estimating the trend of M3 income velocity underlying the reference value for monetary growth" by C. Brand, D. Gerdesmeier and B. Roffia, May 2002.

4 "Labour force developments in the euro area since the 1980s" by V. Genre and R. Gómez-Salvador, July 2002.

5 "The evolution of clearing and central counterparty services for exchange-traded derivatives in the United States and Europe: a comparison" by D. Russo, T. L. Hart and A. Schönenberger, September 2002.

6 "Banking integration in the euro area" by I. Cabral, F. Dierick and J. Vesala, December 2002.

7 "Economic relations with regions neighbouring the euro area in the "Euro Time Zone" by F. Mazzaferro, A. Mehl, M. Sturm, C. Thimann and A. Winkler, December 2002.

8 "An introduction to the ECB's survey of professional forecasters" by J. A. Garcia, September 2003.

9 "Fiscal adjustment in 1991-2002: stylised facts and policy implications" by M. G. Briotti, February 2004.

10 "The acceding countries' strategies towards ERM II and the adoption of the euro: an analytical review" by a staff team led by P. Backé and C. Thimann and including O. Arratibel, O. Calvo-Gonzalez, A. Mehl and C. Nerlich, February 2004.

11 "Official dollarisation/euroisation: motives, features and policy implications of current cases" by A. Winkler, F. Mazzaferro, C. Nerlich and C. Thimann, February 2004.

12 "Understanding the impact of the external dimension on the euro area: trade, capital flows and other international macroeconomic linkages" by R. Anderton, F. di Mauro and F. Moneta, March 2004.

13 "Fair value accounting and financial stability" by a staff team led by A. Enria and including L. Cappiello, F. Dierick, S. Grittini, A. Maddaloni, P. Molitor, F. Pires and P. Poloni, April 2004.

14 "Measuring Financial Integration in the Euro Area" by L. Baele, A. Ferrando, P. Hördahl, E. Krylova, C. Monnet, April 2004. 
15 "Quality adjustment of European price statistics and the role for hedonics" by H. Ahnert and G. Kenny, May 2004.

16 "Market dynamics associated with credit ratings: a literature review" by F. Gonzalez, F. Haas, R. Johannes, M. Persson, L. Toledo, R. Violi, M. Wieland and C. Zins, June 2004.

17 “Corporate 'Excesses' and financial market dynamics" by A. Maddaloni and D. Pain, July 2004.

18 "The international role of the euro: evidence from bonds issued by non-euro area residents" by A. Geis, A. Mehl and S. Wredenborg, July 2004.

19 "Sectoral specialisation in the EU a macroeconomic perspective" by MPC task force of the ESCB, July 2004.

20 "The supervision of mixed financial services groups in Europe" by F. Dierick, August 2004.

21 "Governance of securities clearing and settlement systems" by D. Russo, T. Hart, M. C. Malaguti and C. Papathanassiou, October 2004.

22 "Assessing potential output growth in the euro area: a growth accounting perspective" by A. Musso and T. Westermann, January 2005.

23 "The bank lending survey for the euro area" by J. Berg, A. van Rixtel, A. Ferrando, G. de Bondt and S. Scopel, February 2005.

24 "Wage diversity in the euro area: an overview of labour cost differentials across industries" by V. Genre, D. Momferatou and G. Mourre, February 2005.

25 "Government debt management in the euro area: recent theoretical developments and changes in practices" by G. Wolswijk and J. de Haan, March 2005.

26 "The analysis of banking sector health using macro-prudential indicators" by L. Mörttinen, P. Poloni, P. Sandars and J. Vesala, March 2005.

27 "The EU budget - how much scope for institutional reform?" by H. Enderlein, J. Lindner, O. Calvo-Gonzalez, R. Ritter, April 2005.

28 "Reforms in selected EU network industries" by R. Martin, M. Roma, I. Vansteenkiste, April 2005.

29 "Wealth and asset price effects on economic activity", by F. Altissimo, E. Georgiou, T. Sastre, M. T. Valderrama, G. Sterne, M. Stocker, M. Weth, K. Whelan, A. Willman, June 2005. 
